\title{
Chapter 17 \\ Economics of Land Degradation and Improvement in Niger
}

\author{
Bokar Moussa, Ephraim Nkonya, Stefan Meyer, Edward Kato, \\ Timothy Johnson and James Hawkins
}

\begin{abstract}
Niger's colonial and post-independence natural resource management policies contributed to land degradation. The country also experienced a prolonged drought that amplified the suffering of the people who are heavily dependent on natural resources. The country learnt hard lessons from its past mistakes and changed its policies and strategies. This study shows a strong association of the policy changes and improved human welfare demonstrating that even poor countries could achieve sustainable development. Enhancing government effectiveness by giving communities mandate to manage natural resources and by giving incentives to land users to benefit from their investment played a key role in realizing simultaneous improvement in land management and human welfare in Niger. Given these achievements, Niger was picked as a case study to showcase its achievement and what other countries could learn from the country's mistakes and achievements. The analytical approach used focuses on estimation of cost of land degradation, ground-truthing of satellite data and drivers of adoption of sustainable land management practices. Land use/cover change (LUCC) analysis shows that a total of 6.12 million ha experienced LUCC and shrublands and grassland accounted for the largest change. Excluding the desert, $19 \%$ of the land area experienced LUCC. Cropland expansion accounted for about $57 \%$ of deforestation followed by grassland expansion. The cost of land degradation due to LUCC is about 2007 US\$0.75 billion, which is $11 \%$ of the 2007 GDP of US\$6.773 billion and $1 \%$ of the 2001 value of ecosystem services (ES) in Niger. Every US dollar invested in taking action returns about \$6-a level that is quite attractive. Ground-truthing showed high level of agreement between satellite data and communities perception on degraded lands but poor agreement in areas for which satellite data showed land improvement.
\end{abstract}

\footnotetext{
B. Moussa ( $\square)$

INRAN/NIGER, BP 429, Niamey, Niger

e-mail: bokarmoussa@gmail.com

E. Nkonya $\cdot$ E. Kato $\cdot$ T. Johnson $\cdot$ J. Hawkins

International Food Policy Research Institute, 2033 K Street NW, Washington,

DC 20006, USA
}

\section{S. Meyer}

International Food Policy Research Institute, Lilongwe 3, Lilongwe 31666, Malawi 
Communities also reported that tree planting and protection were the most common actions against land degradation. Tree planting was done mainly on bare lands to fix sand dunes. In summary, this study shows that severe land degradation and the consequent negative impacts on human welfare is a low-hanging fruit that needs to be utilized by countries as they address land degradation. This implies that instead of abandoning severely degraded lands, strategies should be used to rehabilitate such lands using low-cost organic soil fertility management practices and progressively followed by using high cost inputs as soil fertility improves. Improvement of access to rural services and facilitation of non-farm activities will also lead to faster and greater impacts on adoption of SLM practices and increasing resilience to agricultural production shocks in Niger. As Niger continues to improve sustainable land management, it faces daunting challenges to alleviate the high cost of land degradation. Niger serves as a success story to the world in addressing land degradation. Both the national and international communities need to learn from the achievement of Niger and help land users to sustainably manage their natural resources.

Keywords Niger - Land degradation - Livestock • Land use/land cover change • Pasture management practices - Grazing biomass productivity

\section{Introduction}

With a population of only 18 million people over a land area of 1.27 million $\mathrm{km}^{2}$, Niger's population density of 14 people per $\mathrm{km}^{2}$ is one of the 30 most sparsely populated countries in the world. About $77 \%$ of the land area is in the Sahara desert, where rainfall is only $150 \mathrm{~mm}$ per year (CNEDD 2005). The remaining $23 \%$ of the land area in the Southern part of the country is home to a majority of the people, $87 \%$ of whom depend on rainfed agriculture. The arid and semiarid lands (ASAL) under which the farmers live are prone to drought risks which lead to calamities. The drought in 1977-1985 led to loss of $50 \%$ of the livestock population (RoN 2006). Since 1900, there have been 13 drought events, each leading to death of about 6500 people and affecting more than 2 million people (CRED 2014). About $60 \%$ of the population live below the poverty line and since the 1990s Niger has been classified among the poorest countries in the world. Its human development index - an index of measuring longevity and healthy life, knowledge and a decent standard of living has been below 0.4 (UNDP 2014). ${ }^{1}$

Despite this gloomy picture, the sun is rising in Niger! The country has made significant progress in reducing poverty and deprivation. The country has also witnessed an improvement in governance and more sustainable management of its natural resources, upon which the majority of the poor depend. This chapter discusses land

\footnotetext{
${ }^{1} \mathrm{HDI}$ ranges from 0 to 1 , with $\mathrm{HDI}=1$ being the highest level of development and 0 as the lowest level.
} 
degradation and improvement and the government land-based policies and strategies implemented with an objective of reducing rural poverty and improve human welfare. The country's significant achievement in addressing land degradation serves as a good example for other low income countries. The chapter first begins with discussion of the natural resource management policies and strategies and their impacts on human welfare. To set the stage for land degradation and improvement analysis, this section is followed by a discussion on land management practices and productivity. This is followed by a discussion on methodological approach used in the study. A discussion on the economics of land degradation then follows. The chapter ends with lessons learnt and policy implications for Niger's natural resource policies and their impacts on human development.

\section{Historical Context of Nigerien Natural Resource Management Policies}

Niger's economic development serves a powerful case study on how policies and institutions ${ }^{2}$ could lead to land degradation and how they could incentivize farmers to practice sustainable land management (SLM). Our definition of SLM has been contested (e.g. see Kaphengst 2014). For the purpose of this study, we define SLM as land management that maintains or improves ecosystem services for human wellbeing, as negotiated by all stakeholders (Winslow et al. 2011). However, we will refer to land management as SLM if it is an improvement over the commonly used land degrading management practices even when such practice does not maintain or improve terrestrial ecosystems. Before colonialism, Niger had customary unwritten right of axe law - which stipulated that a farmer who clears land owns it (Gnoumou and Bloch 2003). The Law of the Axe was made worse by the French colonial laws 'Aubreville Decree' of 1935, which made all vegetation the property of the government and farmers were required to purchase permits to cut and use wood-even when such trees were on their own farms (Brough and Kimenyi 2002; Montagne and Amadou 2012). Another decree given in the same year stipulated that all lands not occupied or used for more than 10 years becomes state property-even when such land belonged to a farmer but lying fallow (Boffa 1999). Both laws served as disincentives for farmers to invest in tree planting or protection. After independence in 1960, the Nigerien government slightly changed the French law as it maintained ownership of most economically valuable tree species on both protected areas and private lands (Boffa 1999). For example, its 1974 Forest code listed most economically valuable trees as 'protected species' (Boffa 1999; Rinaudo 2005). Due to weak enforcement of the forest code, naturally occurring trees were cut without replacement and this led to severe loss of tree cover.

\footnotetext{
${ }^{2}$ According to North (1991), institutions are formal and informal regulations that structure political, economic and social interaction. They include laws, statutes, taboos, code of conduct, etc.
} 
Matters were made worse by the prolonged drought that led to loss of vegetation and decimated over $50 \%$ of the existing livestock (RoN 2006). Firewood collection - done mainly by women - became a one day task. The natural resource scarcity also led to intensification of conflicts between transhumant pastoralists and sedentary farmers over water and terrestrial biomes (trees, croplands, and grazing lands). Tree scarcity and the massive loss of livestock and other impacts of land degradation required the Nigerien government to reconsider its natural resource management policies and strategies. The section below discusses the policy reforms.

\section{Natural Resources and Agricultural Policy Reforms}

Consistent with Cooke et al. (2008), the dire scarcity of trees and tree products changed the community's perception from tree cutting to clear land to tree planting and protection. The tree scarcity also affected the livestock sector, especially in the central part of Niger, where trees are used as fodder during the dry season. The government also responded to this land degradation by promoting tree planting. As part of the decentralization process in the 1990s (Mohamadou 2009), the Nigerien government passed the Rural Code (Principe d'Orientational du Code Rural Ordinance) in 1993. This law was developed after a consultative process initiated in 1986, and was intended to establish a framework for synthesizing and ultimately replacing the complex and sometimes overlapping set of tenure rights existing under customary, Islamic, colonial and state laws and rules (Toulmin and Quan 2000). The goal of the Rural Code was to integrate customary systems into formal law, drawing upon in-depth studies of local farming, pastoral and forestry practices (Lavigne et al. 2002). It sought to provide land tenure security, to organize and manage rural lands, and to plan and manage natural resources (Gnoumou and Bloch 2003). The Rural Code recognized private land rights only when they are acquired through customary law or written contracts (République du Niger 2003). The Rural Code also gives customary leaders the role of resolving land conflicts and enacting natural resource management (NRM) by-laws (Toulmin and Quan 2000; Lavigne and Delville 2002).

The Rural Code addressed four main issues: protection of the rights of rural operators, conservation and management of natural resources, organization of rural peoples (farmers, herders) and regional land use planning. To complement the Rural Code, the 2004 forestry law also gave tree tenure - i.e., a farmer who plants trees or protects trees on her farm owns it and could use it in any way she wanted (Adam et al. 2006; Stickler 2012).

The Nigerien institutional changes implemented in the 1990s to 2011 had a favorable impact of government effectiveness - quality of public services, civil service and the degree of its independence from political pressures, the quality of policy formulation and implementation, and the credibility of the government's 


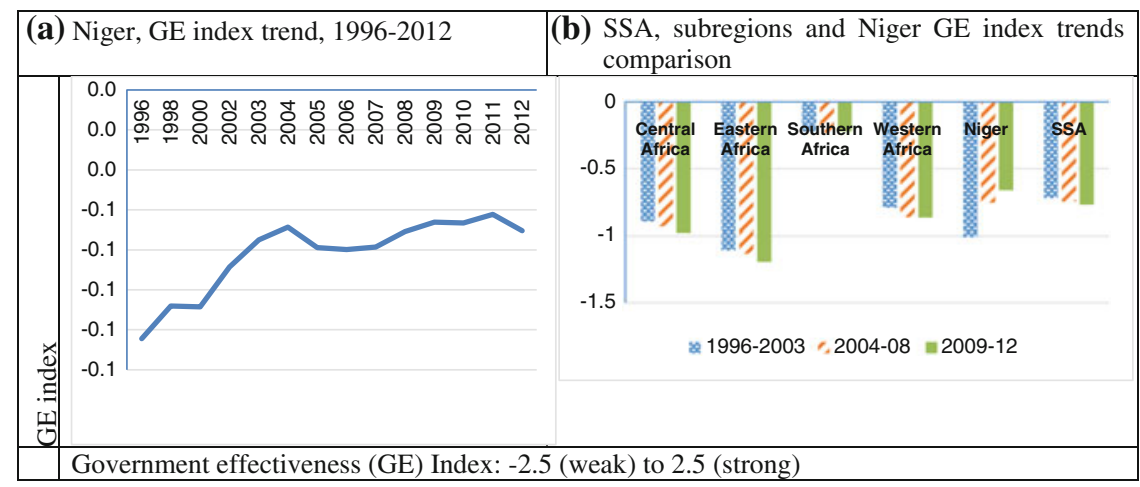

Fig. 17.1 Trend of government effectiveness, SSA and Niger. Source Calculated from http://data. worldbank.org/data-catalog/worldwide-governance-indicators

commitment to such policies (Kaufman et al. 2010). Figure 17.1 shows that the government effectiveness (GE) index rose in Niger by about $43 \%$ while it fell in SSA and Western Africa sub-region. The Nigerien GE index in 2009-12 period was greater than the corresponding average in both SSA and Western Africa. This reveals the significant progress the country made in the two decades.

Improvement in government effectiveness and community perception of natural resources showed a significant impact on natural resources. In addition to allowing communities to own and benefit from trees - thus incentivizing them to plant and protect trees - the Rural Code and other institutional reforms received strong support of civil society that provided significant technical support (Sendzimir et al. 2011). In collaboration with NGOs and international donors, the government initiated tree planting and protection (Reij et al. 2009). Since then, communities and farmers felt much greater ownership over the trees on their land. It is estimated that at least 3 million hectares of land has been reforested since the early 1980s in Niger, largely as a result of community tree planting and natural regeneration of trees (Adam et al. 2006). This is about 2.5 times the forest area of 1.2 million ha in 2012 (FAOSTAT 2014). The tree planting and protection programs contributed to what is known as the regreening of the Sahel (Anyamba et al. 2014; Sendzimir et al. 2011). There was significant increase in rainfall in the Sahelian region that explained the increased vegetation from 1994 to 2012 (Anyamba et al. 2014). However, after controlling for wetter conditions, Herrmann et al. (2005) observed residual increase in greenness that was not explained by increased precipitation. The residual greenness was concentrated in the Projet Intégré Keita (PIK), and where other tree planting and protection programs operated (Reij et al. 2009; Pender et al. 2009).

As Fig. 17.2 shows, the Nigerien forest area declined rapidly in the 1990s, but the rate of loss slowed down beginning in 2001. Such a slowdown could be linked to the lagged impact of the policy changes discussed above. 


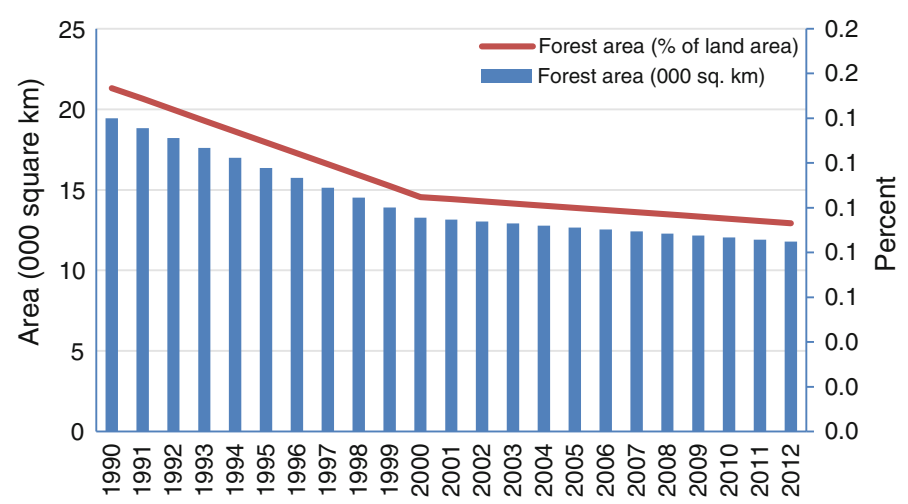

Fig. 17.2 Niger forest area trend, Note FAO's forest data available only from 1990. Source FAO (2012)

Illustrating the Nigerien success story that resulted from policy and institutional changes that provided incentives for land operators to plant and protect trees, the area of planted forest as a percent of the total forest area in Niger was greater than the corresponding percent in three other countries (Fig. 17.3).

A large area of degraded land has been rehabilitated through a presidential program on land rehabilitation and several donor funded projects. According to Adam et al. (2006), at least 250,000 ha of land have been rehabilitated using tree planting and soil and water conservation (SWC) measures since the mid-1980s. The rehabilitated land is about $16 \%$ of the 16 million ha cropland in 2012 (FAOSTAT 2014).

The 1997 Memorandum for Orientation for Livestock Policy, and the 1998 Strategic Orientation Document (DOS) for the agricultural sector specify that sustainable land management (SLM) is a precondition for sustainable agricultural

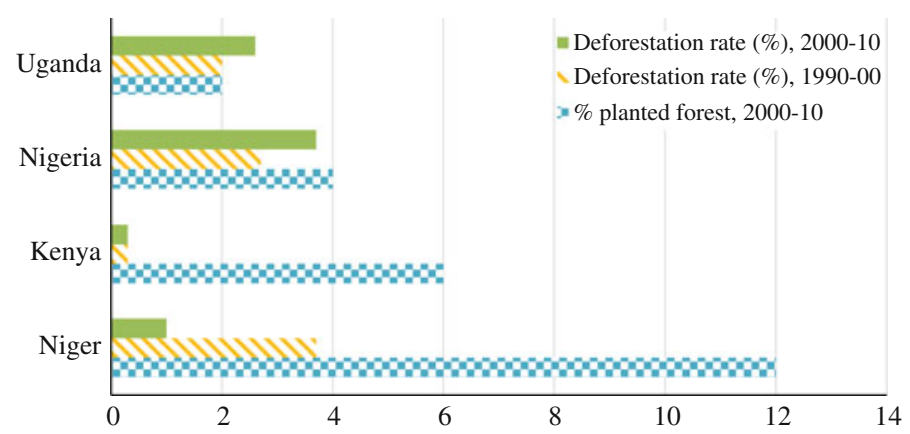

Fig. 17.3 Deforestation rate and planted forest as share of total forest area in selected countries. Source Calculated from FAO (2012) 
development. This policy framework gives a clear mandate for mainstreaming SLM in all ministries that affect land management significantly. Niger is also one of the 37 countries in the world that have revised their national forest policy (NFP) to include sustainable forest management (SFM) (FAO 2014). Niger's NFP also specifically links SFM and ecosystem services (Ibid).

Consistent with DOS, Niger formulated its Poverty Reduction Strategy (PRS) in 2002 , in which SLM is one of the key strategies for poverty reduction. To address risky production in the mainly rainfed agriculture, the PRS promotes diversification and intensification as key elements of agricultural development. The PRS is supported by the 2003 Rural Development Strategy (RDS), in which promotion of sustainable natural resource management, profitable agricultural production and food security are among its main objectives (République du Niger 2003). To achieve its goals sustainably, the RDS aims at decentralization of natural resource management (NRM) by building the capacity of the rural institutions to manage natural resources and rural development in general.

Niger has ratified all three Earth Summit conventions-United Nations Convention to Combat Desertification (UNCCD), Convention on Biological Diversity (CBD) and Framework Convention on Climate Change (UNFCC). Accordingly, Niger created Termit and Tin Toumma National Nature and Cultural Reserve in 2007, which covers $97,000 \mathrm{~km}^{2}$ or $14 \%$ of the land area (Sahara Conservation Fund 2007). To address desertification and land degradation in general, the government adopted the UNCCD convention in 2000 and prepared its national Action Plan (NAP). The NAP sets short-term and long-term plans to address land degradation through promotion of sustainable pasture management, water harvesting, tree planting, developing livestock markets, and other strategies.

Niger designed the national adaptation plan of action (NAPA) in 2006, which identified 14 climate change adaptation action strategies with the broad objectives of food security, sustainable resource management, and poverty reduction. The 14 strategic activities are achieved through the following broad activities: (1) pasture and rangeland improvement; (2) increasing livestock productivity by improving local livestock breeds; (3) development and protection of water resources for domestic use, irrigation, and livestock; (4) promotion of sustainable land and water management (SLWM) practices that enhance adaptation to climate change; (5) promoting peri-urban agriculture and nonfarm activities; (6) building the capacity and organizational skills of rural community development groups; (7) preventing and fighting against climate-related pests and diseases; and (8) dissemination of climate information.

As is the case in other countries however, the total budget set for Niger's NAPA is small and its implementation is short-term (two to three years). Investment in the NAPA has also been largely funded by donors, with limited contribution by the government. This reveals the weak political will of the government to put the NAPA into the sustainable and long-term operation required for effectiveness. However, NAPA has spurred country-level policy awareness of climate change and the need to design policies and strategies to enhance adaptation and mitigation. 
Niger has formulated a national plan on soil fertility and water management, whose objective is to promote the use of appropriate technologies for SLWM (RoN 2006). This policy further shows government's sustainable development and its commitment to SLWM. In 2006, the government also adopted a national strategy for sustainable input supply to farmers (SIAD). The inputs being promoted under the SIAD include seed, fertilizers, pesticides, feed, and others. The objectives of SIAD are to ensure regular access to agricultural inputs at a competitive price; to regulate production, marketing and use of agricultural inputs and to strengthen the capacity of farmer organizations to produce and market their products. It is too early to evaluate the SIAD performance. However, if fully implemented SIAD will help in increasing agricultural productivity and will support the national plan on soil fertility and water management and other NRM and agricultural policies. The policy also sets a stage for supporting the growth of the private input sector, which is weak.

Niger subsidizes fertilizer and some donors distribute fertilizer as part of the emergency aid. The government does not involve the private sector in the distribution of donor fertilizer. Instead, it distributes the donated fertilizer through the "central d'approvisionement", the National government agency for input distribution. The government has justified its participation in input distribution as necessary because of the weak private input marketing sector and to ensure regional equity. ${ }^{3}$ However, this approach works against other efforts to promote growth of the private sector. For example, the "IARBIC project" and other projects are helping to establish a private sector for fertilizers and other input distribution. These efforts are being undermined by the free fertilizer distribution.

After trade liberalization in Niger, the government removed most imports and exports taxes on agricultural input and output. The move was aimed at facilitating food imports to address the food deficiency that affects the country frequently. ${ }^{4}$ The move was also aimed at increasing domestic production. This made Niger one of the most liberalized economies in West Africa. Niger is also one of the West African Monetary and Economic Union (UMEOA) and the Economic Community of West African States (ECOWAS). The objective of both economic unions is to remove all tax and barriers among member states. Niger agricultural exports go mainly within the region (ECOWAS and UMEOA).

The discussion reveals that Niger has designed a number of policies aimed at correcting the old programs that contributed to land degradation and to respond to new global and national changes. The section below discusses the trends and patterns of human welfare in order to understand the potential impact which such changes could have made. The discussion is not meant to attribute the changes directly to policy changes, but rather to establish an association that could help to better understand the environment-human welfare linkage (Reynolds et al. 2011).

\footnotetext{
${ }^{3}$ Discussion with some government officials and researchers in Niger also revealed that the government uses the free distribution of fertilizer to gain political credit during election seasons.

${ }^{4}$ Only imported rice is taxed.
} 


\section{Trends of Human Welfare Indicators and Their Relationship with Policy and Institutional Changes}

The Nigerien human development index (HDI) - a statistical indicator of a country's social and economic development that is calculated using life expectancy at birth, mean years of schooling, expected years of schooling and gross national income per capita - has been improving in the past three decades along with other low human development countries (Fig. 17.4). Despite this development however, Niger remains well below the average of the HDI of other low development index countries.

The Nigerien HDI improvement is strongly correlated with the agricultural sector development and important rural development programs. Microdosingwhich involves placing seeds in planting basin systems, i.e., planting holes made to harvest water, in which a small amount of organic inputs and inorganic fertilizer are placed (Tabo et al. 2009) ${ }^{5}$ - has been increasing in Niger due to promotion by government extension agents, international research organizations, and civil societies (Pender et al. 2009). Accordingly, the rate of nitrogen fertilizer application rate in Niger increased by over $60 \%$ from its average level 2002-05 to 2009-12 (Fig. 17.5). This was the largest increase in West Africa-though the average application rate in Niger is lower than the rate in Western Africa and SSA. The low application rate in Niger is due to the semi-arid conditions, high cost of fertilizer and limited access to credit (Pender et al. 2008). Accordingly, increase in inorganic fertilizer application in Niger is strongly associated with an exponential increase in the crop production index from 1996 to 2012 (Fig. 17.5b). Milk and beef production per capita also increased significantly after the devastating decline during prolonged drought in 1977-1985 (Fig. 17.6). The regreening of the Sahel could have improved pasture and consequently livestock productivity.

Figure 17.7 shows that the percent of the population with malnutrition in 201214 Niger fell by about $60 \%$ compared to its level in 1990-92. The corresponding change in Western Africa and SSA was 43 and $25 \%$ respectively. Accordingly, the global hunger index (GHI) - a multidimensional statistical index depicting severity of hunger in a country (Von Grebmer et al. 2013) and infant mortality rate (IMR) number of children under five years who die per 1000 live births (WHO 2014) have both been falling (Fig. 17.7).

Even though there may be no direct connection between the improving human development indicators and the government policy and institutional changes, the two have a strong correlation that suggest a causal relationship. Indeed, the sun is rising in Niger.

To set the stage for the methodological analysis of the economics of land degradation, the next section discusses land degradation and improvement and livestock and crop productivity in Niger.

\footnotetext{
${ }^{5}$ Microdosing is also referred to as precision conservation agriculture (PCA) (Twomlow et al. 2009).
} 


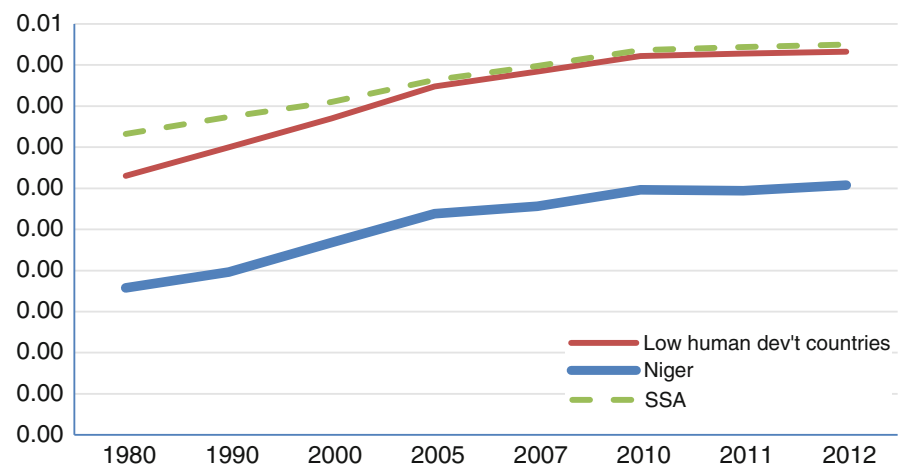

Fig. 17.4 Nigerien human development index trend, 1980-2012, Note HDI ranges from $0=$ lowest human development to $1=$ highest human development. Source UNDP (2013)
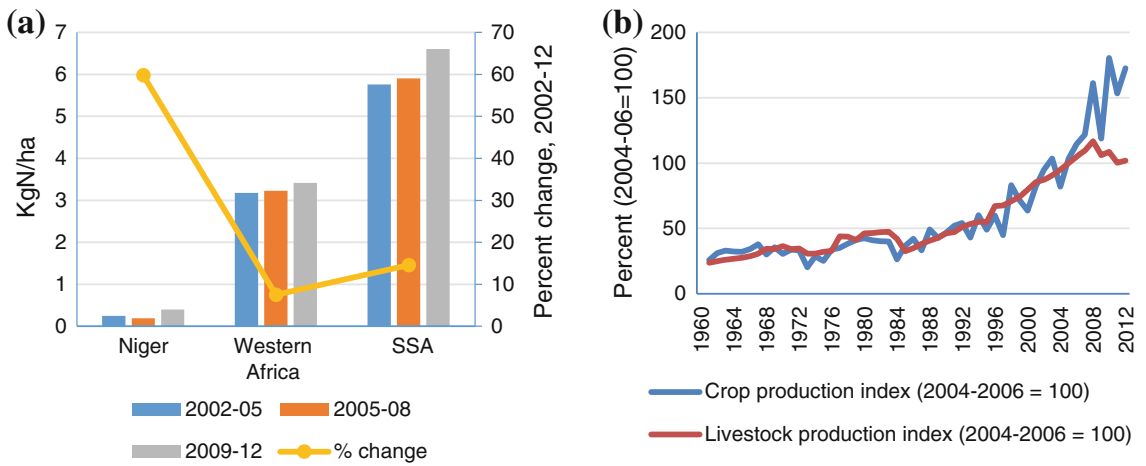

Fig. 17.5 Trend of Nitrogen fertilizer application rates and agricultural, 1990-2012, a Fertilizer application rate. b Trend of agricultural productivity, Niger. Note Percent $\mathrm{N}$ application rate calculated as follows: $\Delta \%=\frac{y_{2}-y_{1}}{y_{1}} \times 100$, where $\mathrm{y}_{1}=$ average application rate, 2002-05, $\mathrm{y}_{2}=$ average application rate, 2009-12. Source Calculated from FAOSTAT (2014)

\section{Land Use/Cover Change, Livestock and Cropland Management and Production in Niger}

As noted in the analytical methods in Chap. 2 and cost of land degradation in Chap. 6 , our analysis will examine the change in the ecosystem services due to land use/cover change (LUCC) and use of land degrading or improving management practices on static cropland and grazing lands (grasslands). 


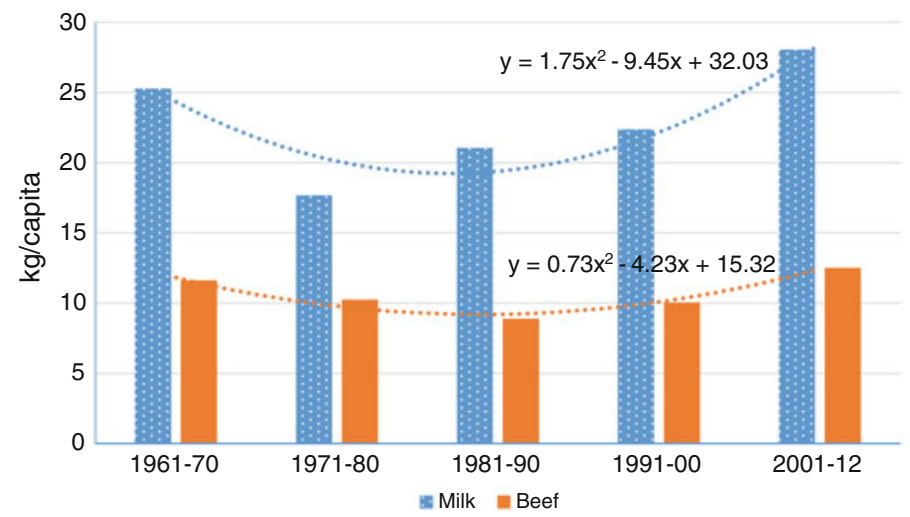

Fig. 17.6 Per capita milk and beef production in Niger

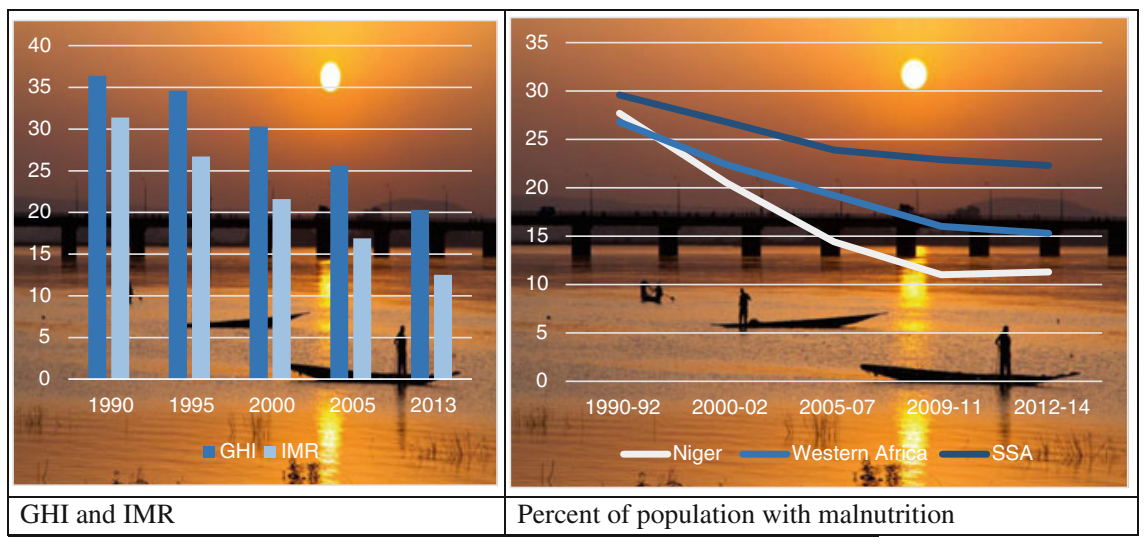

\begin{tabular}{|c|c|c|c|c|}
\hline \multicolumn{5}{|c|}{ Change of malnutrition } \\
\hline Region/subregion & $2000-02$ & $2005-07$ & $2009-11$ & 2012-14 \\
\hline & \multicolumn{4}{|c|}{ Percent change } \\
\hline Niger & 25.99 & 48.01 & 60.29 & 59.21 \\
\hline Western Africa & 16.27 & 28.19 & 40.43 & 42.84 \\
\hline SSA & 9.52 & 19.41 & 22.60 & 24.64 \\
\hline
\end{tabular}

Fig. 17.7 The sun is rising in Niger: trend of infant mortality rate, hunger, and population with malnutrition, Percent change $=\frac{y_{2}-y_{1}}{y_{1}} * 100$, where $y_{2}=$ Percent of population with malnutrition in year $\mathrm{i}, \mathrm{i}=2000-02,2005-07$ to $2012-14, \mathrm{y}_{1}=$ percent of population with malnutrition in year 1990-92. Sources Malnutrition and IMR: World Bank poverty database http://data.worldbank.org/ topic/poverty; GHI: Grebmer et al. (2013). Photo credit (C) iStockphoto.com Jamie Geysbeek "Niger River in the Morning" 
Table 17.1 Change of biome extent, 2001-09, Niger

\begin{tabular}{l|c|c|c|c}
\hline Biome & $2001-05$ & $2006-09$ & Change & $\%$ change \\
\hline Million ha \\
\hline Pasture & 25.08 & 28.78 & 3.70 & 14.8 \\
\hline Forest & 1.29 & 1.24 & -0.056 & -4.3 \\
\hline Cropland & 14.09 & 14.80 & 0.71 & 5.1 \\
\hline Total & 26.37 & 30.02 & 3.65 & 13.8
\end{tabular}

Source Calculated from FAOSTAT (2014)

\section{Land Use/Cover Change (LUCC), 2001-09}

Using year 2001-05 and 2006-09 as baseline and endline respectively, average cropland area increased by $5 \%$ while grazing lands increased by $15 \%$ (Table 17.1). The large increase of the pasture is also due to the regreening of the Sahel (Ouedraogo et al. 2013). Forest extent fell by 56,000 ha or $4.3 \%$. This is not contrary to the tree planting and protection success story discussed earlier because such programs were implemented on private lands that may not lead to forest biomes.

\section{Livestock Production}

Livestock contributes $35 \%$ of Nigerien agricultural GDP (Kamuanga et al. 2008). Niger has a population of 9.214 million heads of cattle or about one head of cattle for each two people. A livestock production system is predominantly pastoral with 26 and $38 \%$ of the household engaged in pastoral and agropastoral production systems respectively (Table 17.2). The average herdsize is 11 and the maximum size is 122 . Cows account for $40 \%$ of the herdsize. However, livestock productivity is low. The average daily milk production per cow in Niger is only 1.41 , a level which is comparable with overall average of 1.61 per day per local breed cow in the Sahelian region (Desta 2002). ${ }^{6}$ This is due to the low rainfall, poor rangeland management, and poor livestock breeds. Only about $4 \%$ used improved pasture management - suggesting that degraded grasslands dominate the production systems. Milk off-take per lactation is $185 \mathrm{~kg}$ in the ASAL and $750 \mathrm{~kg}$ in the sub-humid and humid areas (Otte and Chilonda 2002). As individual animal productivity has remained unchanged, changes in production over time has largely been determined by livestock density, as observed by Otte and Chilonda (2011).

\footnotetext{
${ }^{6}$ Milk off-take for local breeds is $524 \mathrm{~kg}$ per lactation period, which lasts 329 days (Desta 2002). This translates to 1.61 per cow per lactation day.
} 
Table 17.2 Livelihoods of rural communities, adoption of pasture management and breeds, productivity and composition of livestock

\begin{tabular}{|c|c|}
\hline Household characteristics & Statistic \\
\hline Own livestock $(\%)$ & 97 \\
\hline Practice rotational grazing $(\%)$ & 2.24 \\
\hline Milk production per day per cow (liters), 3 months after calving & 1.4 \\
\hline - Own cross-bred cattle $(\%)$ & 2.1 \\
\hline \multicolumn{2}{|l|}{ Household production systems (\% of households) } \\
\hline Crop production only & 37 \\
\hline Agropastoral & 38 \\
\hline Pastoral & 26 \\
\hline Households using improved pasture management $(\%)^{\mathrm{a}}$ & 4 \\
\hline Shoats (goats and sheep) herd size & 16 \\
\hline Cattle herd size (number of heads) & 13 \\
\hline Cattle off-take (head of cattle) & 0.16 \\
\hline \multicolumn{2}{|l|}{ Herd composition of cattle $(\%)^{\mathrm{b}}$} \\
\hline Ox & 3 \\
\hline Bull & 15 \\
\hline Cow & 40 \\
\hline Young Bull/Young & 12 \\
\hline Heifer & 12 \\
\hline Calf & 19 \\
\hline Milking cows & 19 \\
\hline Adult cattle & 58 \\
\hline Improved breeds (cross-breed or exotic breeds) & 11 \\
\hline \multicolumn{2}{|c|}{$\begin{array}{l}\text { Notes }{ }^{\mathrm{a}} \text { Improved pasture management include rotational grazing and managed natural } \\
\text { regeneration. No farmer reported planted pasture } \\
{ }^{\mathrm{b}} \text { Calves }=<1 \text { year, young males and heifers }=1-3 \text { years, males }=>3 \text { years (not specified whether } \\
\text { bulls or oxen), cows }=>3 \text { years } \\
\text { Source Extracted from INS (2012) }\end{array}$} \\
\hline
\end{tabular}

\section{Cropland}

Millet, cowpeas and sorghum are the three most important crops accounting for $94 \%$ of cropland area (Table 17.3). Other crops, namely maize and rice are not widely grown due to their high water requirements. However, maize and rice consumption and consequently net import have been increasing. For example, per capita net rice import increased from $8 \mathrm{~kg}$ in 2000 to $11 \mathrm{~kg}$ in 2011 (FAOSTAT 2014). Actual yield achieved by farmers is quite low-especially for cowpea, sorghum and maize, whose farmer yields are less than $50 \%$ of the potential (Table 17.3). This shows the large potential that Niger enjoys in increasing yield and food security. Microdosing and moisture conservation technologies are among the agronomic practices that could be used to simultaneously increase yield and reduce high risk production in the Sahelian region (Tabo et al. 2009). 
Table 17.3 Cultivated area and actual and potential yield of major crops in Niger

\begin{tabular}{l|l|l|l|l|l}
\hline & $\begin{array}{l}\text { Cropland } \\
\text { area (000 ha) }\end{array}$ & $\begin{array}{l}\text { Share of total } \\
\text { cropland }(\%)\end{array}$ & $\begin{array}{l}\text { Actual } \\
\text { yield (Tons/ha) }\end{array}$ & $\begin{array}{l}\text { Yield } \\
\text { potential } \\
\text { (Tons/ha) }\end{array}$ & $\begin{array}{l}\text { Actual yield as \% } \\
\text { of potential (\%) }\end{array}$ \\
\hline Millet & 7100 & 44.4 & 0.5 & 1.0 & 50 \\
\hline Cowpeas & 4900 & 30.6 & 0.2 & 0.8 & 25 \\
\hline Sorghum & 3100 & 19.4 & 0.3 & 1.0 & 30 \\
\hline Rice & 13 & 0.1 & 1.9 & 3.0 & 63 \\
\hline Maize & 13 & 0.1 & 0.9 & 2.0 & 45 \\
\hline Total & 15126.5 & 94.5 & & & \\
\hline $\begin{array}{l}\text { Total } \\
\text { cropland } \\
\text { area }\end{array}$ & 16,000 & 100 & & & \\
\hline
\end{tabular}

Sources Calculated from FAOSTAT (2014): farmer yield, cropland area; ILO JASPA (1981): Yield potential millet, rice and rice; Tabo et al. (2009) yield potential sorghum

Building on the discussion above and on Chaps. 2 and 6, the discussion below focuses on the analytical approach. The discussion gives more details on aspects that are specific to Niger and to data used in this chapter.

\section{Analytical Approach}

Our analytical approach focuses on estimation of cost of land degradation, groundtruthing of satellite data and drivers of adoption of sustainable land management practices. To take into account the high production risks in Niger, we also estimate the Just-Pope mean-variance model to determine the land management practices that farmers could use to reduce production risks (Just and Pope 1979, 2003).

\section{Cost of Land Degradation}

The approach used for assessing land degradation is discussed in Chap. 6. There few differences in the approach, which are briefly discussed below.

\section{Land Degradation on Static Cropland}

We add millet - the most important staple crop in Niger and drop wheat, which is not a common crop in the country. However, we use the same crop simulation approach to determine the impact of land degradation on static cropland. 


\section{Land Degradation on Grazing Lands}

\section{Impact of Land Degradation or Improvement on Livestock Productivity}

We assess livestock productivity using beef and milk offtake only. This approach ignores other effects of pasture degradation such as parturition and mortality rate. Parturition could increase while mortality rate could fall due to better pasture intake. Rufino et al. (2009) find that adding supplements to diets increases calving rate among smallholder Kenyan dairy farms. Huttner et al. (2001) reports that malnutrition is a major factor predisposing cattle to poor health among Malawian smallholders. Like the case for crops, we estimate the impact of grazing biomass change on livestock productivity using two scenarios:

Business as usual (BAU) — Continuous grazing and improved pasture management -rotational grazing which allows natural regeneration of grasslands. Choice of rotational grazing as an improved forage management is done due to the observation that a number of farmers reported to have used it.

Consistent with Havlic et al. (2014), forage productivity under continuous and rotational grazing was estimated using EPIC model estimated in Sokoto Nigeria by Izzaraulde (2010). The biophysical and socio-economic characteristics of the sites selected in Sokoto were comparable with those selected in Southern Niger (Nkonya et al. 2015). Grazing biomass productivity under BAU and rotational grazing was simulated with the EPIC model, establishing a generic, perennial $\mathrm{C} 4$ species and grazing regime during the rainy season (June 1-October 31) and a livestock density of $1 \mathrm{TLU} / \mathrm{ha}$. Continuous grazing was set such that animals could continue grazing until biomass reduces to a minimum amount of plant dry matter of $0.1 \mathrm{Mg} / \mathrm{ha}$. Rotational grazing scenario allowed 15-day resting periods in-between to allow for grass natural regeneration.

It is important to establish the feed requirement of grazing animals and match this with available pasture. The feed requirement will provide the potential productivity of livestock. Assuming the animals feed on forage with specific nutrient properties, the quantity of feed intake will vary depending on the characteristics of the animal. Specifically, the body weight, growth rate, milk production, and activity level of the animal will jointly determine the level of intake required. Stéphenne and Lambin (2001) estimated the DM biomass consumption per TLULivestock in the Sahelian zone to be 4.6 tons/year based on the following:

- Average daily dietary requirements are $6.25 \mathrm{~kg}$ DM per TLU (Houérou and Hoste 1977; Behnke and Scoones 1993; Leeuw and Tothill 1993).

- Consumable forage of grasses is only one-third of the above-ground biomass (Penning de Vries and Djitèye 1982; Leeuw and Tothill 1993). This means requirement must be multiplied by a factor of 3 to account for this.

- Shrubs, trees and crops residues contribute $33 \%$ of livestock biomass requirements (Houérou and Hoste 1977; Pieri 1989). 
This translates to $6.25 \mathrm{~kg} * 365 * 3 * 2 / 3=4.6$ tons/year/TLU. The feed requirement was used to determine the cost of land degradation in the areas experiencing overgrazing but not practicing rotational grazing. The feed requirement was also used to determine the grazing area experiencing overgrazing. Overgrazing occurs when

$$
o v r=T L U \text { density }>\frac{\text { biom }}{4.6}
$$

where ovr = overgrazing; TLU density is the TLU density per ha; biom = grazing biomass productivity (tons of dry matter per ha per year).

Given that the TLU density data are available for only 2005, we extrapolated it over nine periods using the FAOSTAT national livestock population data and assumed the livestock distribution remained unchanged.

\section{Impact of Forage Intake on Milk Production}

Consistent with NRC (2001) and Muia (2000), we estimate the response of milk production to dry matter intake using a linear equation:

$$
y_{i}=a+b x,
$$

where $y_{i}=$ daily milk offtake of cow $i, x=$ dry matter intake (DMI) per day. To determine the impact of feeding practices only, this equation assumes all other cow nutritional and health requirements are fixed at optimal levels. Table 17.4 reports some results of the impact of dry matter intake (DMI) on milk off-take in Kenya and USA. The study by Muia (2000) is appealing since the constant and coefficient of the equation were determined under controlled experiments in SSA. However, Muia (2000) determined the impact of feed intake on milk yield using zero-grazed Friesian cows in Kenya - an aspect that requires calibrating the model to fit the predominantly local cows raised by farmers in Niger. Dairy cows were fed with

Table 17.4 Linear regression coefficients of dry matter intake impact on daily milk off-take per cow

\begin{tabular}{l|l|l|l|l}
\hline & $\begin{array}{l}\text { Constant } \\
\text { term }\end{array}$ & Coefficient & $\begin{array}{l}\text { Study } \\
\text { country }\end{array}$ & Comments \\
\hline $\begin{array}{l}\text { NRC } \\
(2001)\end{array}$ & - & 2.17 & USA & Weight of cow 450 kg \\
\hline $\begin{array}{l}\text { Muia } \\
(2000)\end{array}$ & 0.18 & 0.77 & Kenya & $\begin{array}{l}\text { Friesian cow weighing 450 kg. } \\
\text { Napier and Leucaena }\end{array}$ \\
\hline $\begin{array}{l}\text { Muia } \\
(2000)\end{array}$ & 0.98 & 0.87 & Kenya & $\begin{array}{l}\text { As above, but cows fed with } \\
\text { Napier and concentrate }\end{array}$ \\
\hline
\end{tabular}


Napier grass supplemented with Leucaena legume. However, the added supplement had only a marginal impact on milk productivity since the slope of the equation with Napier grass, Leucaena and concentrates is 0.87 (Table 17.4).

Muia (2000) used Napier grass (Pennisetum purpureum) — which is tropical grass suitable in tropical humid environment, which is not widely distributed in Niger. Additionally he used improved breeds, which account for only $2.1 \%$ of cattle in Niger. This suggests the need to test the model and modify it to take these challenges into account. We evaluated the model performance in predicting milk yield after feeding on the common forage in Southern Niger. To address the different offtake of local and improved breeds, we introduce a technology scalar, which is a ratio of milk production for local and cross-bred cows. Given the above, the loss of milk production due to land degradation is given by the following model

$$
m_{t}=\sum_{t=4}^{T} a\left[0.18+0.77\left(D M I_{t}^{c}-D M I_{t}^{d}\right)\right] x_{t}
$$

where $\mathrm{m}_{\mathrm{i}}=$ total milk production in year $\mathrm{t}$, DM $I_{t}^{c}=$ dry matter biomass intake $\left(\mathrm{kg} / \mathrm{head}\right.$ per day) for cows grazing under rotational grazing; $\mathrm{DMI} l_{t}^{d}=$ dry matter biomass intake $(\mathrm{kg} / \mathrm{head}$ per day) for cows grazing under continuous grazing; $\mathrm{t}=$ year, $\mathrm{t}=4 \ldots 0.9 ; \mathrm{a}=$ technology coefficient given by $a=\frac{m_{l}}{m_{e}}$, where $\mathrm{m}_{1}=$ daily milk production of one local cow; and $\mathrm{m}_{\mathrm{e}}=$ daily milk production of one exotic cow used by Muia (2000) and $x_{t}=$ number of milking cows in year in overgrazed grasslands in $\mathrm{t}$.

We start to detect the impact of improved pasture management in the fourth year $(\mathrm{t}=4)$ because we assume that grassland biomass increase due to rotational grazing will reach an equilibrium in year 3 . The annual biomass productivity per ha in Niger ranges from 0.21 to 2.02 tons DM/ha with an average of 0.63 tons DM/ha (Havlic et al. 2014). Based on LSMS household survey data collected in 2012, the daily milk offtake per local cow ranges from 0.5 to 41 with an average of $1.4 \mathrm{~kg}$. Muia et al. (2000)'s one Friesian cow fed with $12.2 \mathrm{~kg}$ DM of Napier grass per day and supplemented with sunflower produces $11.7 \mathrm{~kg}$ of milk. Using these data to calibrate Muia's model shows that the average milk production is overestimated by only $10 \%$ (Table 17.5) - suggesting that the technology factor $\mathrm{a}=0.90$.

Table 17.5 Calibration of the Muia (2000) model to local cow breeds

\begin{tabular}{l|l|l|l|l}
\hline $\begin{array}{l}\text { Biomass } \\
\text { productivity } \\
\text { statistics }\end{array}$ & $\begin{array}{l}\text { Annual } \\
\text { biomass } \\
\text { (tons/ha) }\end{array}$ & $\begin{array}{l}\text { Equivalent } \\
\text { daily DMI } \\
\text { (kg/cow) }\end{array}$ & $\begin{array}{l}\text { Milk offtake } \\
\text { per cow } \\
\text { (kg/day) }\end{array}$ & $\begin{array}{l}\text { \% of actual milk } \\
\text { offtake of local } \\
\text { cows }\end{array}$ \\
\hline Average & 0.63 & 1.8 & 1.6 & 110 \\
\cline { 2 - 5 } & 1.00 & 2.7 & 2.3 & 160 \\
\hline Maximum & 2.02 & 5.5 & 4.4 & 317 \\
\cline { 2 - 5 } & 5.50 & 15.1 & 11.8 & 840 \\
\hline
\end{tabular}


To determine milk production during the reference period, we compute the cow herd growth model proposed by Upton (1989):

$$
x_{t+1}=(1+\beta-\omega) x_{t}-\tau x_{t},
$$

where $x_{t}=$ cow herd in year $t ; \beta=$ growth rate of heifer into cows; $\omega=$ cow mortality rate; $\tau=$ cow offtake rate.

We set the growth rate of cow herd to reach an equilibrium that matches the average herd size, i.e.,

$$
x_{t+1} \leq \bar{x},
$$

where $\bar{x}=$ average cow herd. Since we estimate cow herd growth rate at national level, we do not include stolen cows since we assume such theft is a transfer within Niger.

\section{Impact of Forage Intake on Beef Production}

We compute the impact of land degradation or improvement using the meat off-take only and ignoring the change in weight for livestock which were not sold or slaughtered. Based on Blench (1999), the feed conversion ratio (kg grazed dry matter per change $(\mathrm{kg})$ in live weight) is 7:1 for cattle and 10:1 for sheep and goats (shoats). This suggests the extra $100 \mathrm{~kg}$ of forage due to improved pasture management (e.g. rotational grazing) would convert in gains of $14 \mathrm{~kg}$ of live weight for cattle and 10 of live weight for shoats. However, these comparisons should be taken with caution since they apply mostly to European breeds, which may have different behavior from indigenous cattle breeds in Niger.

Based on the discussion of milk and meat offtake changes due to feed intake, we estimate the cost of land degradation from 2001 to 09 on overgrazed grassland using the following model:

$$
C L D_{\text {grass }}=\sum_{t=4}^{T}\left[m_{t} p_{m}+o f f\left(b^{c}-b^{d}\right) p_{b}+\tau \Delta C O_{2} a\right]
$$

where $\mathrm{CLD}_{\text {grass }}=$ Cost of land degradation in Niger; $\mathrm{m}_{\mathrm{t}}=$ as defined in Eq. (17.5), $b^{c}$ and $b^{d}=$ meat production under improved and unimproved pasture management; $\mathrm{P}_{\mathrm{b}}=$ price of beef per $\mathrm{kg} ; \mathrm{P}_{\mathrm{m}}=$ price of milk per kg; off = livestock offtake rate (slaughter and sales of live animals); $\Delta \mathrm{CO}_{2}=$ change in the amount of carbon sequestered under SLM and BAU and $\tau=$ price of $\mathrm{CO}_{2}$ in the global carbon market and $\mathrm{a}=$ area being overgrazed. 
Table 17.6 Land status and primary economic activities in the selected communities, 2013

\begin{tabular}{l|l|l|l|l|l|l}
\hline Community & KoneBeri & Tiguey & Bazaga & Babaye & Djibiri & Bla Birin \\
\hline Population & 2734 & 1616 & 1712 & 1061 & 37 & 84 \\
\hline Land status & Degraded & Degraded & Improved & Degraded & Improved & Degraded \\
\hline
\end{tabular}

Primary activities of households

\begin{tabular}{l|c|c|c|c|c|l}
\hline Crop production & 80 & 80 & 90 & 80 & 30 & 10 \\
\hline Livestock & & 10 & 7 & & 17 & \\
\hline Crop/livestock & 15 & & & 15 & 20 & 70 \\
\hline Forest & & & 3 & & 3 & \\
\hline Fisheries & & & & & 15 & \\
\hline Non-farm & 5 & 10 & & 5 & 15 & 20 \\
\hline
\end{tabular}

Source Authors

\section{Groundtruthing and Focus Group Discussion}

Focus Group Discussions (FGD) were conducted in seven Nigerien communities shown in Fig. 17.9. The communities were selected to cover AEZ and to represent areas that Le et al. (2014) showed land improvement or land degradation in each AEZ (see Table 17.6). All seven communities fell into one agroecological zonethe arid and semiarid land (ASAL), i.e., with rainfall below $700 \mathrm{~mm} /$ year. Approximately 10-20 community members participated in the FGD. KoneBeri, Tiguey, Bazaga, and Babaye are predominantly crop producers while Djibiri and Bla Birin are pastoral and agropastoral communities. Le et al. (2014) classify Bazaga and Djibiri as having experienced land improvement while the rest of the communities experienced land degradation (Fig. 17.8).

Participants were purposely selected to represent old people who could give informed perception on land use change over the 30 year reference period; women, the youth, local government leaders, crop producers, livestock producers, people who earn their livelihoods from forest and other non-agricultural terrestrial biomes, and customary leaders. Such a diverse groups afforded a rich discussion on ecosystem value and their change from 1982 to 2012 .

Groundtruthing remote sensing data was done by asking FGD members to show the LUCC and land degradation or improvement of the major biomes which have occurred in the community over a 30 year period (1982-2012). Groundtruthing helps to determine reliability of the satellite data used in this report. Results of the groundtruthing are reported in Chap. 5 of this book.

\section{Drivers of Adoption of SLM and Risk Reducing Land Management Practices}

Drivers of adoption of SLM: We estimate the drivers of adoption of ISFM, inorganic fertilizer, organic inputs and crop rotation using a Probit model specified as follows: 


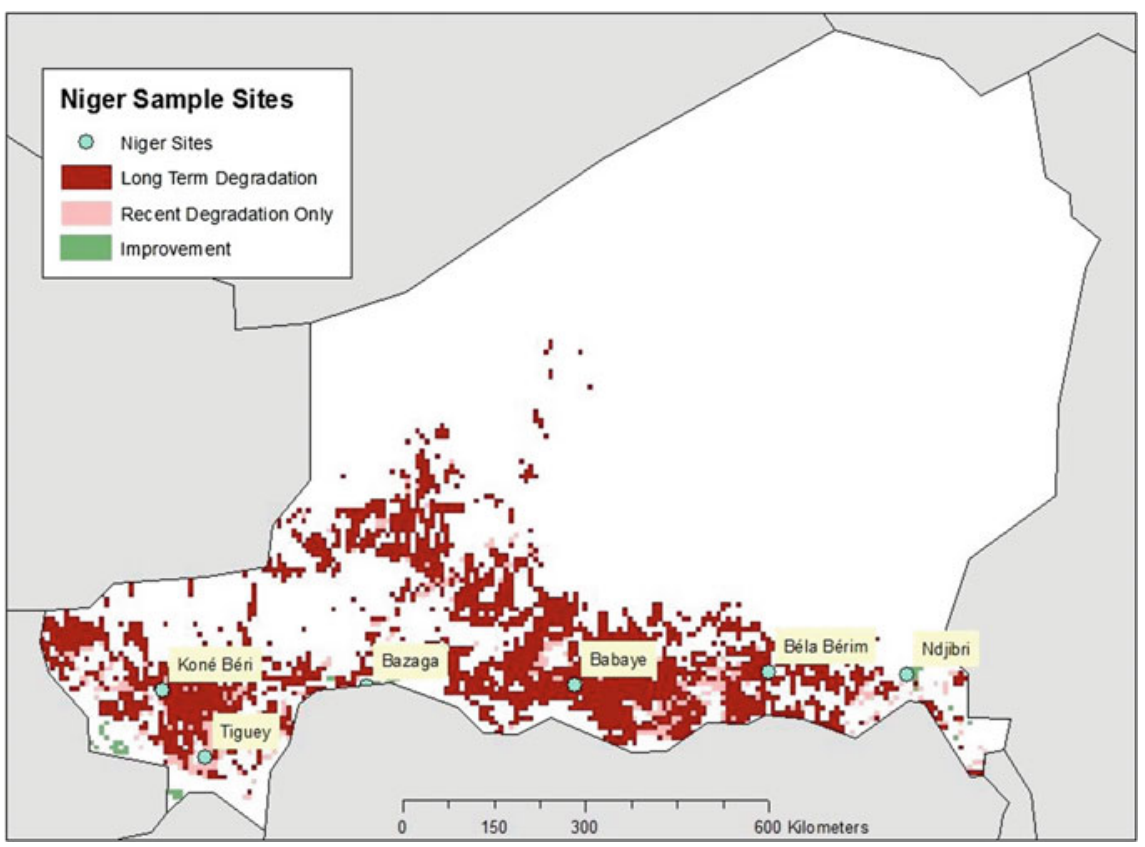

Fig. 17.8 Case study communities selected for FGD and groundtruthing

$$
\mathrm{Y}^{*}=\Phi-1(\mathrm{Y})=\mathrm{X} \beta+\varepsilon
$$

where $\mathrm{Y}^{*}$ is a latent variable, such that

$$
Y=\left\{\begin{array}{ll}
0 & \text { if } Y^{*} \leq 0 \\
1 & \text { if } Y^{*} \geq 1
\end{array},\right.
$$

$\Phi$ is a cumulative normal distribution with Z-distribution, i.e., $\Phi(Z) \epsilon(0,1), \mathrm{X}$ is a vector of covariates of drivers of adoption of land management practices and $\beta$ is a vector of the associated coefficients. $\mathrm{X} \beta \sim \mathrm{N}(0,1)$; $\varepsilon$ is an error term with normal distribution, i.e., $\varepsilon \sim \mathrm{N}(0,1)$.

Choice of the elements of the $\mathrm{X}$ vector in the empirical model is guided by literature $^{7}$ and data availability. We include some variables that are potentially endogenous. To address the endogeneity bias, we estimate a reduced form model and an instrumental variable linear probability model (IV-LPM) (Horace and Oaxaca 2006). The LPM has two major problems: (i) some estimates of probability are above 1 and are meaningless. The farther away from 0 to 1 interval, the more biased and inconsistent the estimates are (Ibid) and (ii) violation of

${ }^{7}$ See Chap. 7 for details. 
homoscedasticity and normality assumptions. The dependent variable as dichotomous variable cannot yield a homoscedastic error term, unless the odds of $p=1$ for all observations are the same and that the error term is not normally distributed, given that there are only two values ( 0 and 1$)$. Following Horace and Oaxaca (2006), it is possible to address both problems by dropping values that lead to coefficients outside the 0 to 1 interval. Estimates are unbiased and are consistent if they lie within the unit interval (ibid). To check robustness of the coefficients, we estimate the structural model and the corresponding IV-LPM and the reduced Probit model.

Impacts of land management on production risks: Given that the land management practices that affect yield also influence risk (variance), we use the Just-Pope mean-variance model:

$$
Y=f(X, C)=p(X, C)+\sqrt{\varphi(X, C) e(\xi)}
$$

where $\mathrm{Y}=$ yield which is affected by a deterministic production function $\mathrm{P}(\cdot)$ and a stochastic risk function $\varphi(\cdot)$ with an error term of unknown random effects $(e(\xi))$ determined by rainfall and other risks and stressors that affect Y. Drivers of $e(\xi)$ are unknown to farmers when they make production decisions.

$\mathrm{C}$ and $\mathrm{X}$ are respectively covariates of land management practices and other covariates, which simultaneously affect $\mathrm{P}(\cdot)$ and $\varphi(\cdot)$.

$$
\begin{aligned}
& \frac{\partial \operatorname{var}(Y)}{\partial C}>0 \rightarrow \text { Risk-increasing land management practice, } \\
& \frac{\partial \operatorname{var}(Y)}{\partial C}<0 \rightarrow \text { Risk-reducing land management practice. }
\end{aligned}
$$

The following section discusses the results of the study, starting with the cost of land degradation due to LUCC.

\section{Cost of Land Degradation Due to LUCC and Community Restoration Efforts}

According to Table 17.7, desert or barren land accounts for about $72 \%$ of the land area. However, excluding the desert, grasslands and shrublands respectively account for 76 and $23 \%$ of the land area. A total of 6.12 million ha experienced LUCC and shrublands and grassland accounted for the largest change (Fig. 17.9 and Table 17.7). Excluding the desert, $19 \%$ of the land area experienced LUCC. Cropland expansion accounted for about $57 \%$ of deforestation followed by grassland expansion (Fig. 17.10). This is consistent with Gibbs et al. (2010) who 
Table 17.7 Extent of major biomes and LUCC in Niger, 2001

\begin{tabular}{|c|c|c|c|c|}
\hline \multirow[t]{2}{*}{ Biome } & \multirow{2}{*}{\begin{tabular}{|l|} 
Area \\
(million ha) \\
\end{tabular}} & \multicolumn{2}{|l|}{ Percent of total area } & \multirow{2}{*}{$\begin{array}{l}\text { LUCC to other } \\
\text { biome(s) } \\
\text { (million ha) }\end{array}$} \\
\hline & & Excluding the desert & Including the desert & \\
\hline Forest & 0.01 & 0.03 & 0.01 & - \\
\hline Shrublands & 7.55 & 23.09 & 6.38 & 3.40 \\
\hline Grasslands & 24.71 & 75.58 & 20.88 & 2.51 \\
\hline Cropland & 0.32 & 0.99 & 0.27 & 0.15 \\
\hline Urban & 0.04 & 0.14 & 0.04 & - \\
\hline Woodlands & 0.06 & 0.17 & 0.05 & 0.04 \\
\hline Desert/barren & 85.65 & - & 72.38 & - \\
\hline
\end{tabular}

Note Change in forest area excluded since it is too small

Source MODIS data

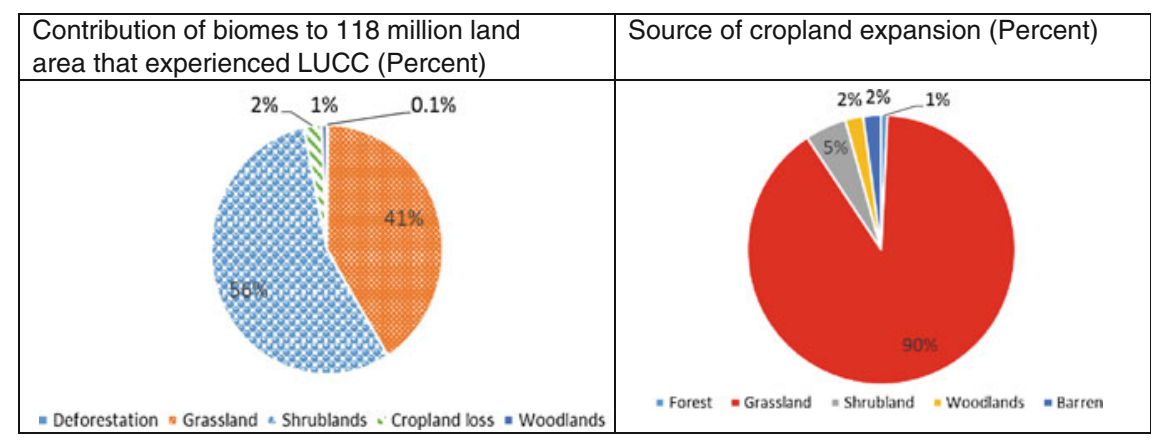

Fig. 17.9 Contribution of major biomes to LUCC and to cropland expansion

also observed forest contributing the largest share of cropland expansion in SSA. However, grasslands accounted for about $90 \%$ of cropland expansion (Fig. 17.9). The changes from high to low value biome leads to land degradation and are considered in the cost of land degradation discussed below.

Cost of land degradation due to LUCC is about 2007 US\$0.75 billion, which is $11 \%$ of the 2007 GDP of US $\$ 6.773$ billion and $1 \%$ of the 2001 value of ecosystem services (ES) in Niger (Fig. 17.11).

The cost of action to address land degradation is US\$5 billion while the cost of inaction is about US\$30 billion over the 30 year planning horizon. As expected the returns for taking action are quite high. Every US dollar invested in taking action returns about $\$ 6-$ a level that is quite attractive.

In the section below, we examine the perceptions of farmers on land degradation to verify the satellite data results discussed above. 


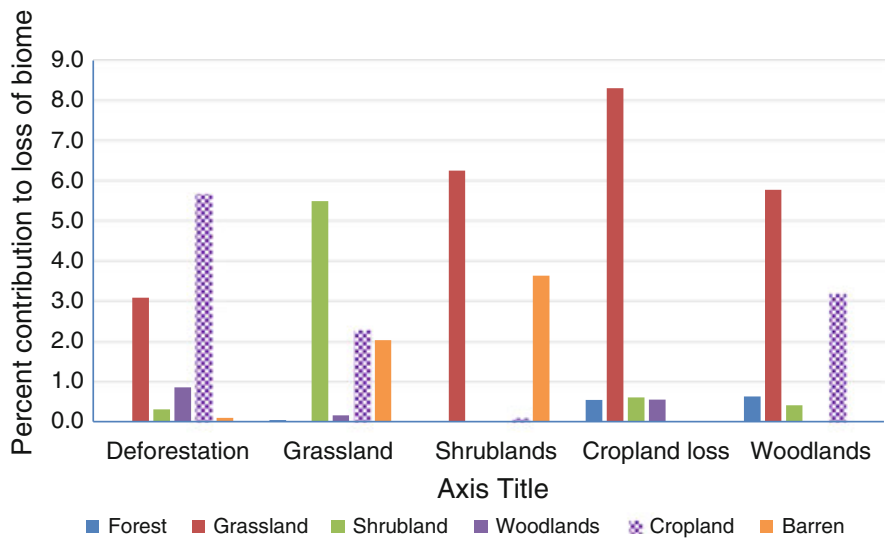

Fig. 17.10 Source of loss of biome extent and destination biome in the LUCCC, Niger

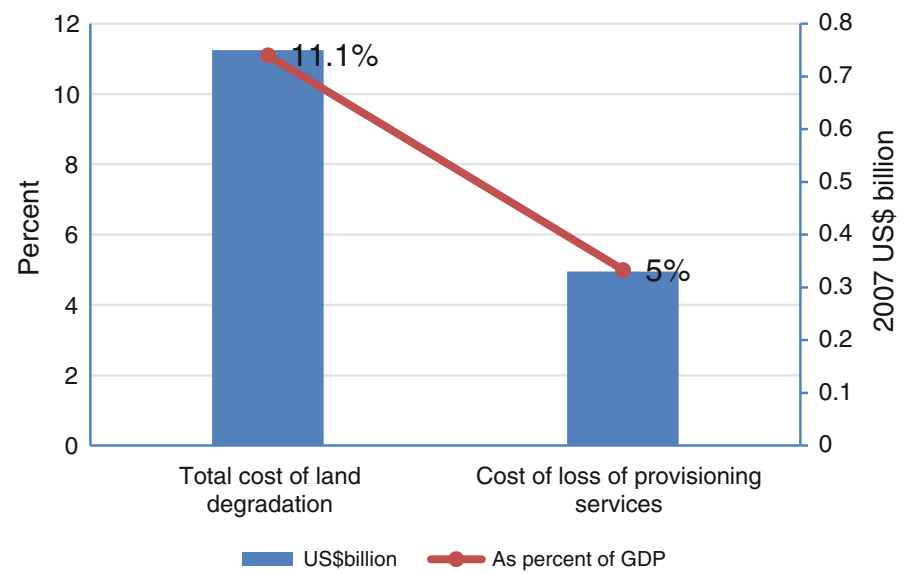

Fig. 17.11 Cost of land degradation due to LUCC, Niger

\section{Focus Group Discussion Results}

\section{Trend of Importance of Ecosystem Services}

Consistent with the MODIS data results, communities perceived that importance of provisioning services fell for both degraded and improved lands. In both cases, the fall in importance-ranked from not important $=1$, somehow important $=2$ and very important $=3$ fell by over $40 \%$ (Fig. 17.12). In the last 30 years, Niger was affected by several severe droughts, locust pests and floods. The events caused a lot of stress for the ecosystem and the farmer's production systems (World Bank 2011) 


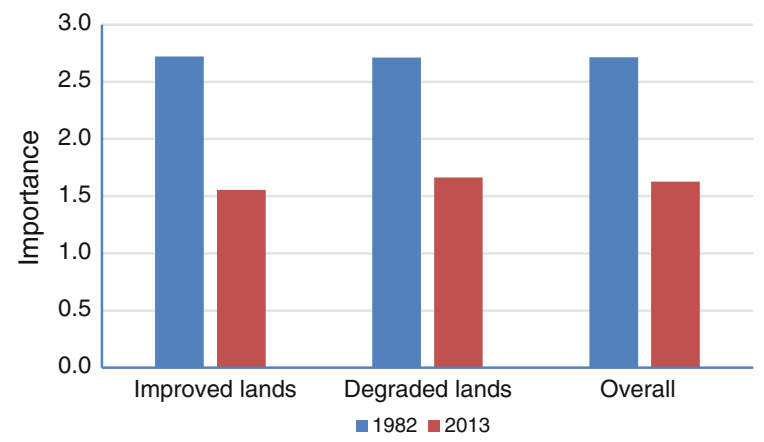

Fig. 17.12 Importance of provisioning services, Niger, Note Importance of ecosystem services: 1 Not Important; 2 Somehow important; 3 Very important; 4 Don't know). Source Authors

and had generally a negative impact on the supply of provisioning, regulating and supporting as well as cultural services. Regulation of air quality, pollination, waste treatment, nutrient cycling and other regulating and supporting systems were affected by these events. Importance of regulating services fell by $52 \%$ the steepest decline of all the ecosystem services.

Detailed analysis of the trends of ecosystem services show that importance of provisioning services declined in both communities with degraded and improved NDVI (Fig. 17.13). However, a look at the specific services in detail reveals that perceptions of the importance of crops were rated the same over the time period from communities with improved lands. In one village (Bazaga), where $90 \%$ of the households primarily produce crops, the importance of provisioning services from crops actually increased. This is consistent with Fig. 17.14-which reports increasing crop productivity. The farmers reported that this increase results from infrastructure development.

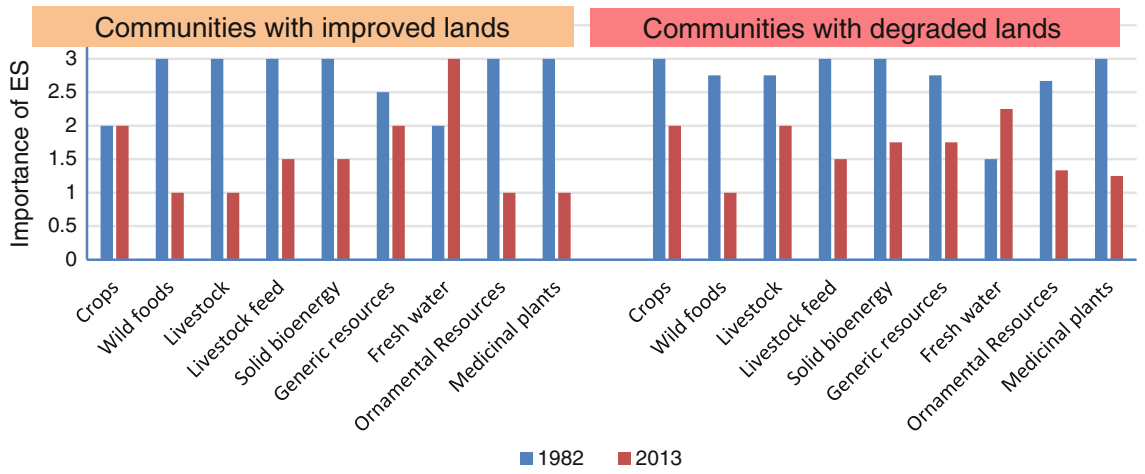

Fig. 17.13 Detailed listing of provisioning services' importance in communities with degraded and improved lands, Niger, Note Importance of ecosystem services (ES): 1 Not Important; 2 Somehow important; 3 Very important), Source Authors 


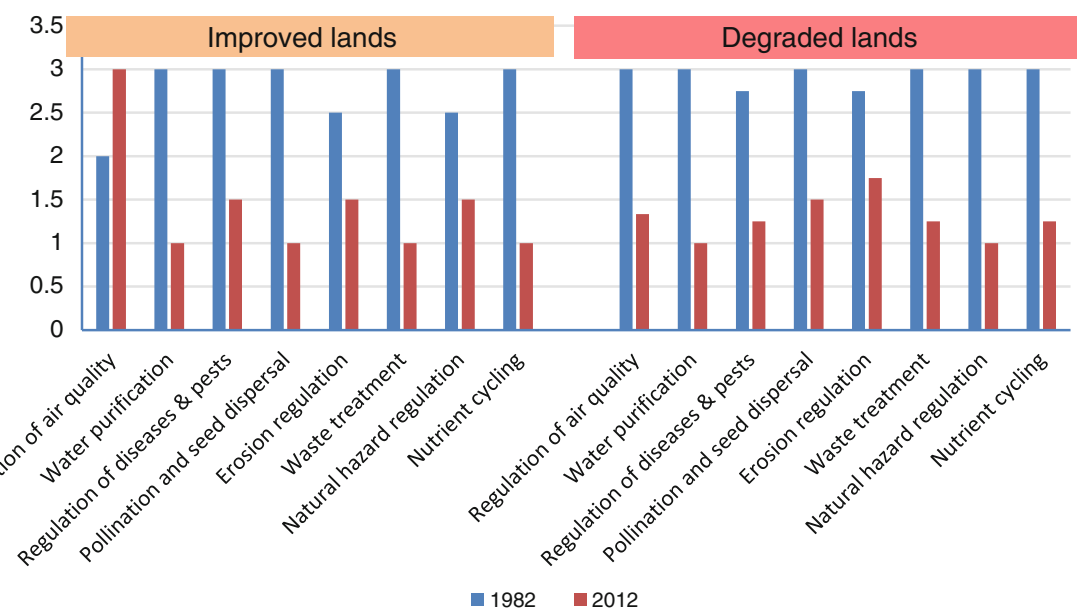

Fig. 17.14 Detailed listing of regulating and supporting services importance, Niger, Notes Importance of ecosystem services in 1982 and 2013: 1 Not Important; 2 Somehow important; 3 Very important); Source FGD

Additionally, a majority of villages stated that they have better access to fresh water in 2012 than was the case in 1982. Publicly financed wells were constructed in the villages. This positive development is mostly due to a transferring of responsibilities for water supply from the national government to local authorities (AMCOW 2011).

Importance of regulating and supporting systems declined in communities with decreased NDVI but increased in villages which experienced higher NDVI (see Fig. 17.15). In villages with an improved NDVI, cleaning of the air is functioning better in 2013 compared to 1982. The participants, who were situated in predominantly crop producing areas, specified that this is a consequence of land improvement. The promotion of improved production technologies increased the soil quality of cropland. For instance, leaving millet stumps after the harvest on the fields, which reduces wind erosion in the dry season, is a successfully applied approach in Niger (Hayashi et al. 2010).

Cultural services were generally declining in importance in nearly all villages. One of the factors driving this change is erosion of traditional values among the youth (Blum 2007). Additionally, a shift from traditional beliefs to Islam is also contributing to movement from traditional spiritual services that nurture nature. Only one village reported that cultural services are improving. The farmers in the community who reported improvement in cultural services attributed the improvement to government promotion of trees, which significantly increased the ability to rest and recover during field work.

Land degradation is the most important reason for the decline of all three types of ecosystem services (see Fig. 17.15). The FGD participants reported that wind 


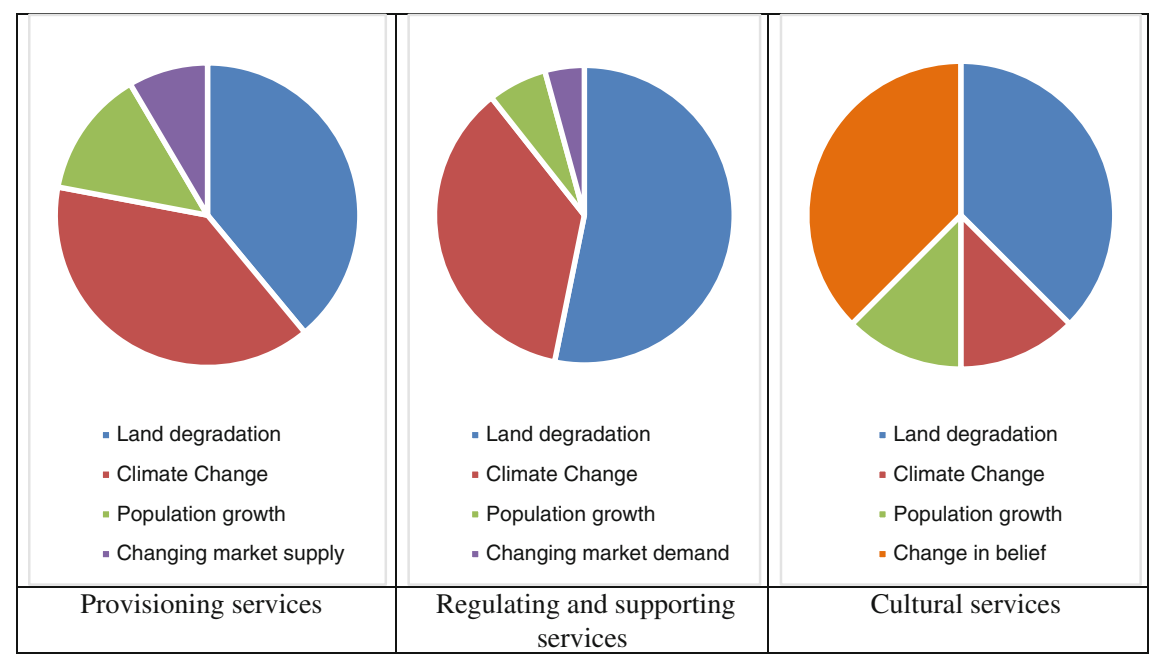

Fig. 17.15 Reasons for the fall in importance of ecosystem services, Niger, Source FGD

and water erosion as well as loss of soil fertility are a consequence of deforestation, poor agricultural techniques and overgrazing. In general, rates of sustainably managed natural resources are still low in Niger, as can be seen by the low fertilizer application rates in Fig. 17.5 or the low application rates of rotational grazing in Table 17.2. Climate Change, especially reduced precipitation, is also an important reason for a decline of provisioning as well as regulating and supporting services.

In general there is a strong agreement between FGD and the MODIS data on land degradation. Chapter 5 reports further on the groundtruthing of satellite data with community perception. The discussion below examines the community response to land degradation.

\section{Restoration of Degraded Lands}

Communities were asked to mention the three most important actions they have taken to address land degradation for each of the major biomes. Communities reported to have taken actions on cropland, grasslands and bare lands only. There were no actions mentioned to address land degradation on forests and shrublands. About $40 \%$ of the communities that reported land degradation on cropland adopted SLWM practices and $13 \%$ passed byelaws to address it (Fig. 17.17). The SLWM practices used include promotion of improved agricultural technologies, application of organic and inorganic fertilizers and other management practices. Other actions taken to address land degradation on cropland include shifting cultivation, tree 
planting, postharvest handling and other actions. ${ }^{8}$ Tree planting was the most common strategy used to restore bare lands. Tree planting was done mainly on bare lands to fix sand dunes. As discussed earlier, this is in line with Niger's tree planting programs that have shown significant impacts.

For grazing land, farmers reported mixed results of the activities reported as other in Fig. 17.17. In Bazaga, farmers received credits for livestock. The larger herd sizes increased the demand for fodder and this led to overgrazing. In contrast, in Babaye the distribution of animals improved grazing land. Vulnerable women received goats, which used to be a traditional income source for female villagers. In Babaye women were not only given access to animals adopted to the irregular precipitation, but also awareness for the changing climate and its consequences, as well as trainings including sustainable fodder production and rotational grazing were provided by an NGO. A similar project was conducted by CBA (2010) in other parts of Niger.

\section{Land Degradation on Static Land Use}

The discussion below focuses on cropland and grazing lands that did not undergo LUCC. As discussed earlier, only $19 \%$ of land south of the Sahara desert experienced LUCC and the remaining land (81\%) maintained the same biome in 2001 and 2009. We start our discussion with adoption and profit of cropland SLM practices.

\section{Land Degradation on Static Grasslands}

Livestock production is mainly concentrated in the southern part of the country and its density increases towards the Nigerian border (Fig. 17.16). Grazing land pressure has been increasing and this has led to reduced biomass productivity. Controlling for rainfall, a long-term experiment of rangeland productivity in Niger showed an annual decrease of $5 \%$ from 1994 to 2006 and the causes of decrease included decreasing soil fertility and increased grazing pressure (Hiernaux et al. 2014).

The increasing grazing pressure suggests some level of overgrazing. The average carrying capacity in the Sahelian region varies from 10 to $3.5 \mathrm{ha} / \mathrm{TLU}$ - depending on the precipitation of each year (Boudet 1975; Penning de Vries and Djitèye 1982). The carrying capacity of livestock in Niger is between 5 and 7 ha per tropical livestock unit (TLU) (Kamuanga et al. 2008). Results of biomass productivity in Niger done by Havlic et al. (2014) show that the average productivity of grazing

\footnotetext{
${ }^{8}$ These prayers and rituals.
} 


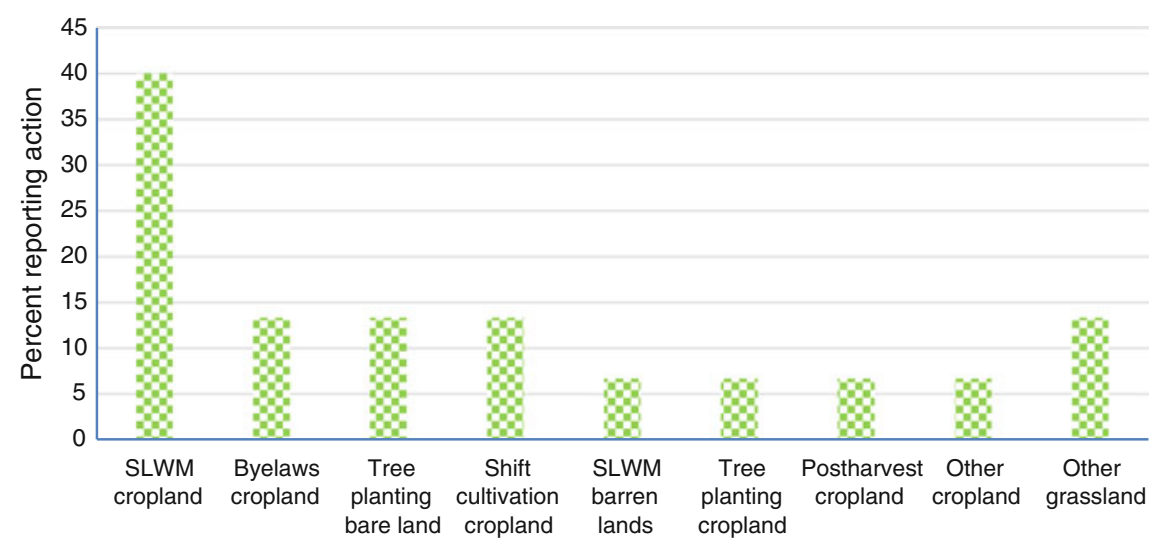

Fig. 17.16 Action taken to address land degradation on major biomes

biomass in Niger is 0.634 tons DM/ha/year. Stéphenne and Lambin (2001) also show that feed requirement per TLU in the Sahelian region is 4.6 tons of dry matter (DM) per year. This translates to a carrying capacity of 7.25 ha per TLU. Based on this, we overlaid the grazing biomass productivity and livestock density and determined that more than $75 \%$ of the grazing lands are experiencing overgrazing. This partly explains the low livestock productivity in the country — an aspect that leads to high cost of land degradation.

Only about $4 \%$ of the households with livestock practice improved pasture management (Table 17.8). The improved pasture management include different forms of rotational grazing and restricted movement of livestock. Based on EPIC simulation discussed earlier, the cost of land degradation due to loss of milk and beef offtake is US\$152 million, which is about $2.2 \%$ of the GDP. Loss of milk production accounts for $88 \%$ of total on-farm loss. Loss of beef offtake is small due to the small offtake rate and the small gain in weight due to rotational grazing (Table 17.9).

Table 17.8 Adoption of pasture management practices and impacts on grazing biomass productivity

\begin{tabular}{|c|c|}
\hline Pasture management & Adoption rate $(\%)$ \\
\hline Rotational grazing & 0.4 \\
\hline Restricted grazing & 0.4 \\
\hline Resting of grazing land & 2.5 \\
\hline Improved pasture management & 3.64 \\
\hline \multicolumn{2}{|c|}{ Pasture management impact on grassland productivity (EPIC simulation results) } \\
\hline Biomass with rotational grazing (dry matter tons/ha) & 0.69 \\
\hline Continuous grazing (dry matter tons/ha) & 0.55 \\
\hline Gain (dry matter tons/ha) & 0.14 \\
\hline
\end{tabular}


Table 17.9 Cost of land degradation due to overgrazing

\begin{tabular}{|c|c|c|}
\hline & Continuous grazing & Rotational grazing \\
\hline Mean milk production per cow per day (l) & 1.7 & 2.1 \\
\hline \multirow[t]{2}{*}{ Beef offtake ( $\mathrm{kg}$ per head sold/slaughtered) } & 0.272 & 0.267 \\
\hline & Without carbon & With carbon \\
\hline \multicolumn{3}{|c|}{ National level cost of land degradation due to loss of: } \\
\hline Milk production & 133 & \\
\hline Beef & 17.8 & \\
\hline Gain in $\mathrm{CO}_{2}$-equiv sequestration (tons/ha) & & 1.29 \\
\hline $\begin{array}{l}\text { Cost of land degradation due to loss of } \mathrm{CO}_{2} \\
\text { sequestration (US\$ million) }\end{array}$ & 691.71 & \\
\hline Total cost of land degradation & 843.33 & \\
\hline Off-farm cost of land degradation as $\%$ of total cost & $82 \%$ & \\
\hline Total on-farm cost of land degradation as \% of GDP & $2.2 \%$ & \\
\hline
\end{tabular}

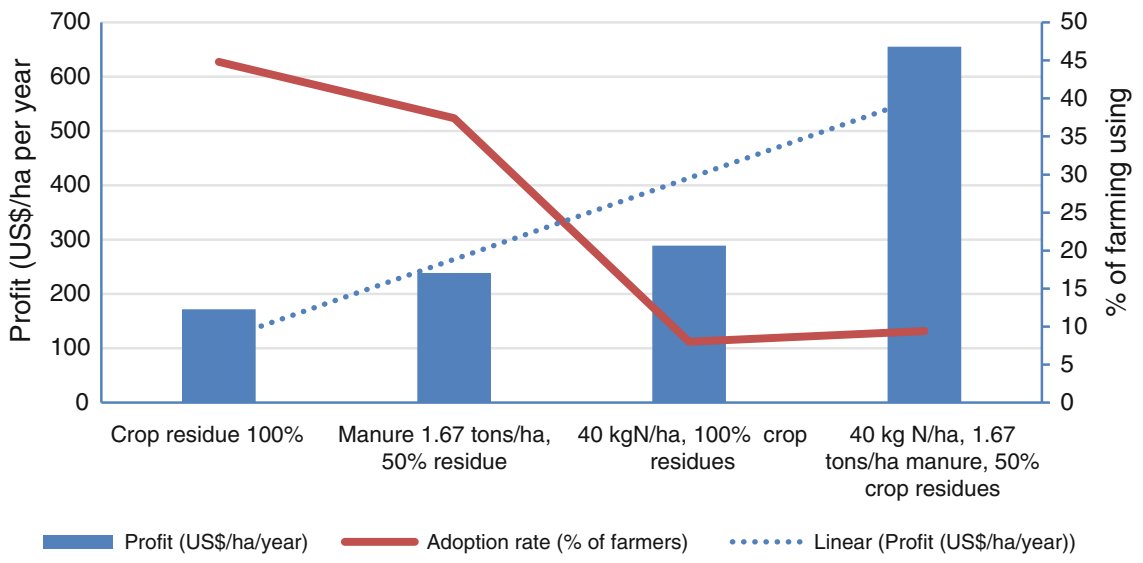

Fig. 17.17 The unholy cross: Inverse relationship between profit and adoption rate of soil fertility management practices on millet plots, Niger

\section{Adoption Rates and Profit of Cropland SLM Practices}

Figure 17.17 shows that while only $9 \%$ of plots received the most profitable practice - integrated soil fertility management (ISFM), i.e., a practice that combines judicious quantities of chemical fertilizer with organic inputs and improved germplasm (Vanlauwe and Giller 2006), about half of the plots did not receive any external inputs - the least profitable management practice. Table 17.10 gives details of adoption rate of the three soil fertility management practices for the four major crops and all consistently show the same pattern-lowest adoption rate for ISFM and inorganic fertilizer and highest use for the least profitable soil fertility 
Table 17.10 Adoption rate of soil fertility management practices for major crops in Niger

\begin{tabular}{l|l|l|l|l}
\hline \multirow{2}{*}{ Crop } & ISFM & Fertilizer only & Organic only & No inputs \\
\cline { 2 - 5 } & \% of plots & with SLM practice & \multicolumn{2}{l}{} \\
\hline Millet $(\mathrm{n}=2174)$ & 9.4 & 8.0 & 72.0 & 10.6 \\
\hline Groundnuts $(\mathrm{n}=459)$ & 14.4 & 7.2 & 72.0 & 6.4 \\
\hline Sorghum $(\mathrm{n}=1253)$ & 11.1 & 6.5 & 72.0 & 10.4 \\
\hline Cowpea $(\mathrm{n}=1121)$ & 12.3 & 9.3 & 72.0 & 6.4 \\
\hline All crops & 8.9 & 9.3 & 33.7 & 8.5 \\
\hline & Mean yields $(\mathrm{kg} / \mathrm{ha})$ & \multicolumn{2}{|l}{} \\
\hline Millet & 521 & 423 & 477 & 340 \\
\hline Groundnuts & 907 & 697 & 349 & 525 \\
\hline Sorghum & 515 & 349 & 411 & 348 \\
\hline Cowpea & 565 & 205 & 300 & 259 \\
\hline A
\end{tabular}

A Includes: manure, crop rotation, agroforestry

management practices. The inverse relationship between profitability and adoption rate of land management suggests there are challenges which hamper farmers from adopting the most profitable land management practices. We look at these in the section addressing drivers of adoption of soil fertility management practices.

Millet accounts for $42 \%$ of cropland in Niger (FAOSTAT 2014) but its yield is much lower than the potential yield. Literature estimates of the low, medium and high yield of pearl millet yield in Eastern and Southern Africa is estimated to be respectively $0.16,0.72$ and 1.93 tons/ha (Tittonell and Giller 2013). However, LSMS household survey show the average yield is 0.92 tons/ha. A long-term experiment in Sadore Niger showed that millet-cowpea rotation improves nitrogen use efficiency from $20 \%$ to $28 \%$ and increased grain yield from 0.516 tons/ha to 1.200 tons/ha - a $57 \%$ increase on plots that did not receive any external inputs (Bationo and Ntare 2000). However household survey data show that $36 \%$ increase in millet-cowpea yield and $72 \%$ of households practiced millet-cowpea rotational cropping (Pender 2009).

We analyze the cost of land degradation due to use of land degrading management practices on maize, rice and millet plots. We use DSSAT results for non-adoption of ISFM and long-term soil fertility experiments on millet-cowpea rotational cropping vs. millet-millet continuous cropping.

DSSAT results on ISFM and non-use of inorganic and fertilizer on maize, rice and millet plots. Table 17.11 summarizes the DSSAT results for all three crops and shows that the total cost of land degradation is US77.44 million. Despite the high adoption rate of rotational cropping, the cost of land degradation due to millet-millet continuous cropping is much larger (US\$154.68 million) due to the large area covered by millet (Table 17.12). The summary of on-farm cost of land degradation on crops covered is US\$318.74 million or $2.5 \%$ of the GDP (Table 17.13). 
Table 17.11 Grain yield and carbon sequestration $\left(\mathrm{CO}_{2}\right.$-equiv $)$

\begin{tabular}{l|l|l|l|l|l|l}
\hline Management practice & \multicolumn{3}{|l|}{ Maize-rainfed } & \multicolumn{2}{|l|}{ Rice-irrigated } & \multicolumn{2}{l}{ Millet-rainfed } \\
\cline { 2 - 6 } & $\begin{array}{l}\text { Grain } \\
\text { yield }\end{array}$ & $\begin{array}{l}\mathrm{CO}_{2^{-}} \\
\text {equiv }\end{array}$ & $\begin{array}{l}\text { Grain } \\
\text { yield }\end{array}$ & $\begin{array}{l}\mathrm{CO}_{2^{-}} \\
\text {equiv }\end{array}$ & $\begin{array}{l}\text { Grain } \\
\text { yield }\end{array}$ & $\begin{array}{l}\mathrm{CO}_{2^{-}} \\
\text {equiv }\end{array}$ \\
\hline & Tons/ha \\
\hline
\end{tabular}

ISFM: $40 \mathrm{kgN} / \mathrm{ha}, 1.67$ tons organic inputs/ha and/or crop rotation

\begin{tabular}{l|r|r|r|r|r|r}
\hline ISFM 1st 10 & 2.5 & 144.32 & 1.7 & 360.7 & 1.3 & 343.0 \\
\hline ISFM last 10 & 2.1 & 133.50 & 1.3 & 271.3 & 1.3 & 327.4 \\
\hline Change (\%) & -15.6 & -7.49 & -23.1 & -24.8 & -0.7 & -4.5 \\
\hline
\end{tabular}

BAU: no inorganic fertilizer, organic inputs or crop rotation

\begin{tabular}{l|c|c|c|c|c|c}
\hline Control 1st 10 & 1.8 & 140.73 & 1.5 & 359.6 & 1.2 & 340.8 \\
\hline Control last 10 & 1.2 & 125.89 & 0.93 & 269.6 & 1.0 & 318.2 \\
\hline Change (\%) & -29.5 & -10.55 & -36.6 & -25.1 & -16.7 & -6.6 \\
\hline $\begin{array}{l}\text { Cost of land degradation } \\
\text { (US\$ million) }\end{array}$ & 2.75 & 4.24 & 1.61 & 3.48 & 21.30 & 77.44 \\
\hline
\end{tabular}

Table 17.12 Cost of land degradation due to millet-millet continuous cropping

\begin{tabular}{l|l}
\hline Management practice & Statistics \\
\hline Adoption rate millet-cowpea rotation cropping & $72 \%$ \\
\hline Area under BAU (000 ha) & 1164.36 \\
\hline Grain yield (tons/ha) & \multicolumn{2}{|l}{} \\
\hline SLM & 1.20 \\
\hline BAU & 0.52 \\
\hline$C O_{2}$-equiv (tons/ha) & \\
\hline SLM & 7.93 \\
\hline BAU & 5.95 \\
\hline Cost of land degradation (US\$) due to: & \\
\hline Grain yield loss & 143.61 \\
\hline $\mathrm{CO}_{2}$-sequestration loss-only millet aboveground dry matter & 11.07 \\
\hline Total cost of land degradation & 154.68
\end{tabular}

Assume producer price of millet of US $\$ 431$

Source Bationo and Ntare (2000). Converted from aboveground dry matter using the following formula: $\mathrm{DM}=\mathrm{C} / 0.45$ (Steeg et al. 2013); $\mathrm{CO}_{2}=3.67 \mathrm{C}$ - Price of $\mathrm{CO}_{2}=\mathrm{US} \$ 20 /$ ton

\section{Drivers of Adoption Rate of SLM Practices on Cropland}

Results across the three models (structural, reduced and LPM-IV) are consistent suggesting they are robust. Additionally, all coefficients of the LPM are below 1 implying that they are less biased and are consistent (Horace and Oaxaca 2006). Results also show consistent relationships between adoption of management practices that involve purchased inputs (inorganic fertilizer and ISFM) and organic soil fertility practices (organic inputs, and rotational cropping) which are produced 
Table 17.13 Summary of cost of land degradation

\begin{tabular}{l|c|c|l|l|l}
\hline \multirow{2}{*}{ Crop } & \multicolumn{2}{|l|}{ Grain yield loss } & $\mathrm{CO}_{2}$ sequestration & Total & \multicolumn{2}{l}{$\begin{array}{l}\text { Cost of land degradation as } \\
\% \text { of GDP }\end{array}$} \\
\cline { 2 - 6 } & 2007 US\$ million & & Total cost & Grain yield loss \\
\hline Maize & 2.75 & 4.24 & 6.99 & 0.10 & 0.04 \\
\hline Rice & 1.61 & 3.48 & 5.09 & 0.08 & 0.02 \\
\hline Millet-ISFM & 21.30 & 77.44 & 98.74 & 1.46 & 0.31 \\
\hline MM-CC & 143.61 & 11.07 & 154 & 2.28 & 2.12 \\
\hline Total & 318.74 & 107.76 & 426.5 & 3.92 & 2.50 \\
\hline \% of GDP & 2.50 & 1.42 & 3.92 & & \\
\hline
\end{tabular}

Notes ${ }^{\mathrm{a}} \mathrm{MM}-\mathrm{CC}=$ millet-millet continuous cropping

on-farm or don't go through the market. Accordingly, our discussion will follow this pattern by referring adoption of inorganic fertilizer and ISFM as land management practices that involve purchased inputs and non-purchased inputs.

Endowment of family male labor has favorable influence on adoption of all four soil fertility management practices while female labor has negative impact on ISFM and inorganic fertilizer-both of which include purchased inputs (Table 17.14). This is consistent with past studies showing favorable impact of male labor on adoption of purchased inputs (e.g. see Peterman et al. 2014). Consistent with Nkonya et al. (2008) and Kaizzi (2002), farmers are more likely to use organic soil fertility management practices and less likely to apply inorganic fertilizer on sandy soils. Farmers tend to avoid using purchased inputs on less fertile soils to avoid losses but tend to use non-purchased organic inputs to rehabilitate degraded soil or those naturally low fertility (e.g. sandy soils). Similarly and by design, zai and demi-lunes are associated with adoption of organic inputs-partly because organic inputs are added into constructed SWC structures - and with less likelihood to use purchased inputs.

Non-farm activities increase the propensity to use purchased inputs (inorganic fertilizer and ISFM). This shows the synergistic relationship between non-farm and farm activities. Contrary to expectation however, remittances and value of assets negative impact on adoption of management practices that involve purchased inputs. The results could be explained by tendency of farmers to focus less on agricultural activities when they become wealthier or when they have alternative sources of income such as remittances. However, values of assets have a favorable impact on adoption of crop rotation. Consistent with the fertility gradient reported by Zingore et al. (2007), plots closer to home are likely to receive both organic inputs and inorganic fertilizer.

\section{Risks and Land Management Practices}

As expected, crop rotation, stone bunds and demi-lunes are risk-reducing land management practices (Table 17.15). This is consistent with recent studies which 


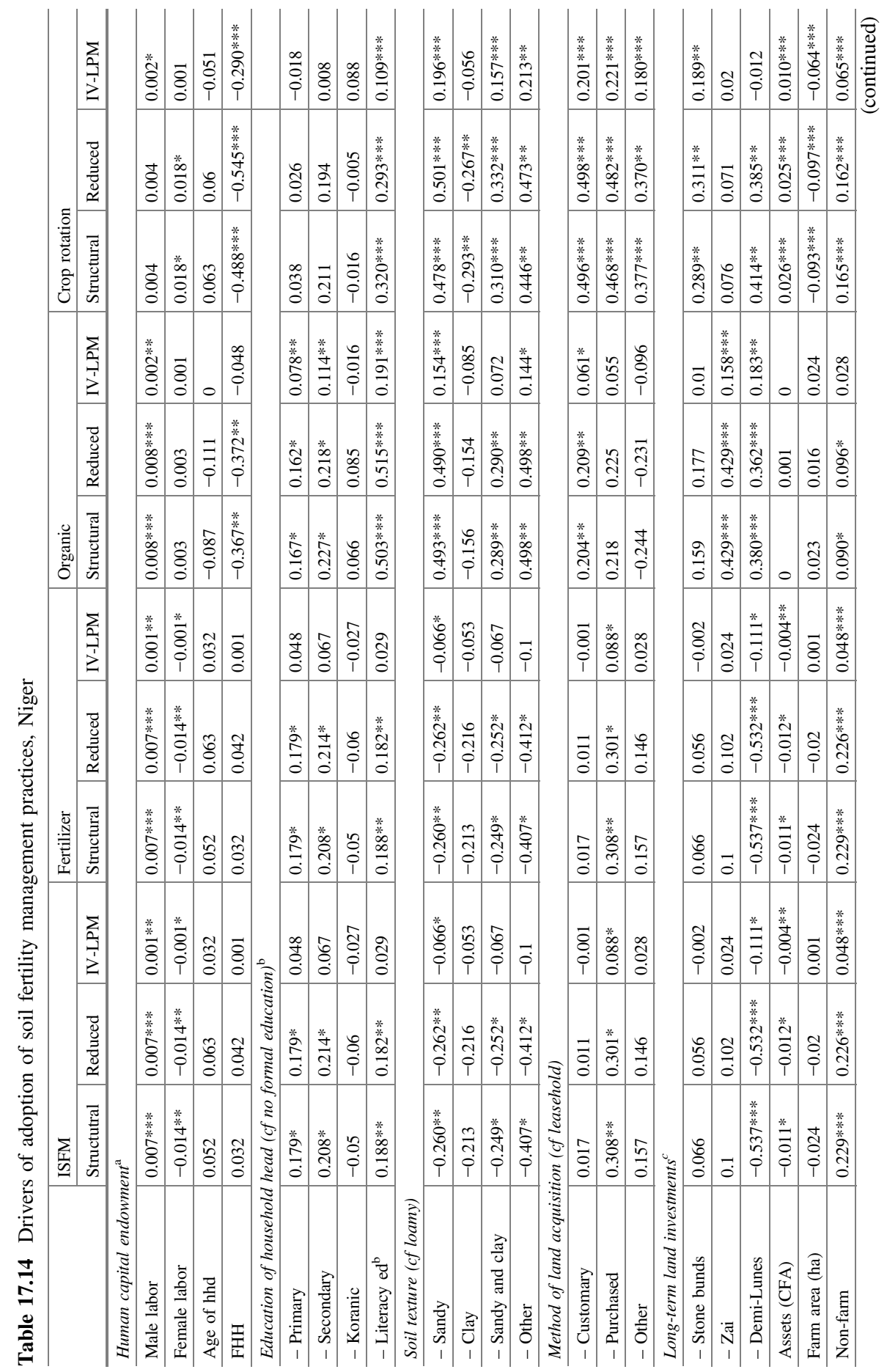




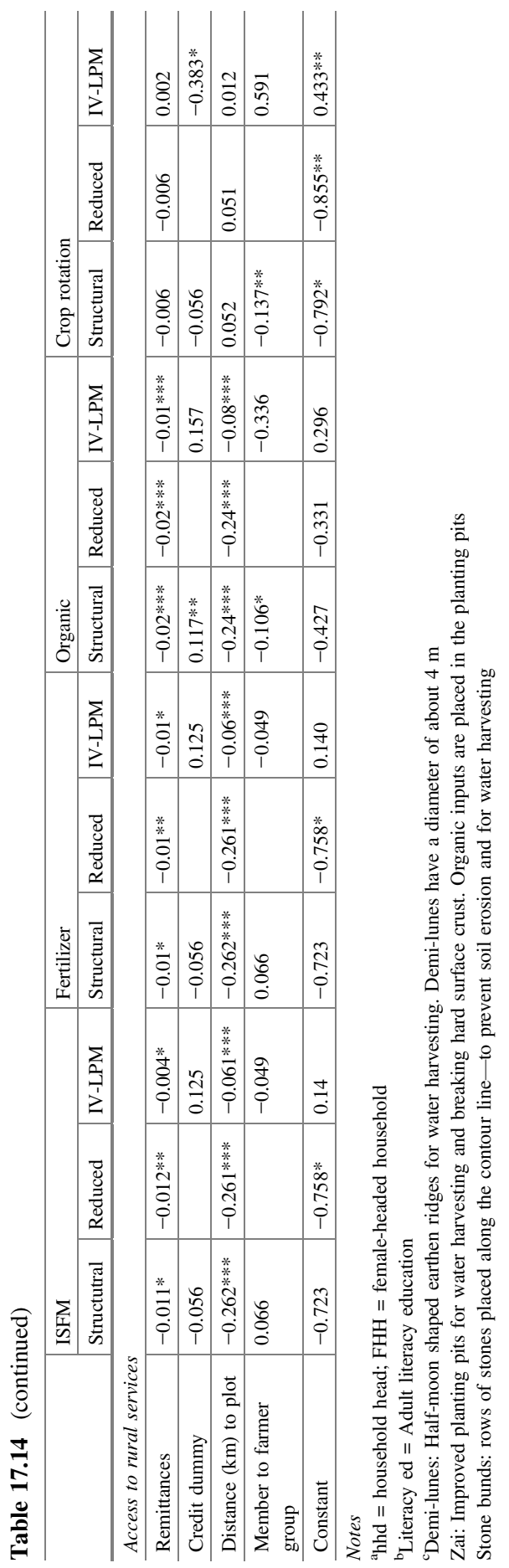


Table 17.15 Drivers of deviation from conditional mean yield (log value of production/ha)

\begin{tabular}{|c|c|}
\hline Variable & Coefficient \\
\hline \multicolumn{2}{|c|}{ Land management practices and long-term investments } \\
\hline Organic inputs & $0.452 * * *$ \\
\hline Inorganic fertilizer & $0.275 * * *$ \\
\hline Crop rotation & $-0.421 * * *$ \\
\hline Stone bunds & $-0.642 * * *$ \\
\hline Zai & $0.287 * *$ \\
\hline Demi-lunes & $-0.579 * *$ \\
\hline \multicolumn{2}{|l|}{ Human capital endowment } \\
\hline Male family labor & 0.001 \\
\hline Female family labor & $-0.024 * * *$ \\
\hline Age of household head & $0.873 * * *$ \\
\hline Female-headed household & $1.427 * * *$ \\
\hline Have non-farm income & $-0.234 * * *$ \\
\hline \multicolumn{2}{|l|}{ Education of household head } \\
\hline Primary & 0.066 \\
\hline Secondary & -0.077 \\
\hline Koranic education & $0.273 * * *$ \\
\hline Literacy adult education & 0.086 \\
\hline \multicolumn{2}{|c|}{ Physical and biophysical capital endowment } \\
\hline Value of productive assets (CFA) & $0.039 * * *$ \\
\hline Farm area (ha) & $0.153 * * *$ \\
\hline \multicolumn{2}{|l|}{ Soil texture } \\
\hline Sandy & 0.137 \\
\hline Clay & $0.613 * * *$ \\
\hline Sandy and clay & $0.374 * *$ \\
\hline Other soil texture & -0.093 \\
\hline \multicolumn{2}{|l|}{ Method of land acquisition (cf leasehold) } \\
\hline Customary (inherit) & $-0.889 * * *$ \\
\hline Purchased & $-0.749 * * *$ \\
\hline Other & $-1.632 * * *$ \\
\hline \multicolumn{2}{|l|}{ Access to rural services } \\
\hline Received remittances & -0.004 \\
\hline Distance to plot from homestead $(\mathrm{km})$ & $-0.164 * *$ \\
\hline Received credit & -0.054 \\
\hline Member to farmer organization & -0.015 \\
\hline Constant & $17.225 * * *$ \\
\hline
\end{tabular}

have demonstrated that water harvesting, and farmer management natural regeneration (FMNR) can both increase agricultural productivity and reduce climate-related risks (AGRA 2014; Garrity et al. 2010; Bayala et al. 2014; Reij et al. 2009; Place and Binam 2013). The results underscores the importance of promoting these practices to increase farmers' resilience to the high production risks in the 
Sahelian zone. Contrary to other studies (e.g. Cooper et al. 2009; Cooper and Coe 2011) however, zai and organic inputs increase yield variance. Likewise, inorganic fertilizers increase yield variance. This could be due to their likely impact in yield variability across relevant but excluded land management and/or soil characteristics. For example response of an inorganic fertilizer to improved crop varieties is greater than is the case for unimproved varieties.

With a number of female household members having non-farm activities, customary land tenure and proximity of plot to home also reduce production risks. The results further underscore the importance of non-farm activities and the role that female household members play in enhancing resilience of households to shocks. The results also show that the plots held under customary tenure are likely to have greater resilience to production risks than those held under leasehold. Proximity of plots to homestead could be a result of better soil fertility management reported by Zingore et al. (2007), which in turn reduces variance (Nkonya et al. 2015). However, female-headed households experience greater yield variance, probably due to their failure to adopt the risk reducing management practices discussed above.

\section{Conclusions and Policy Implications}

Recent policy changes in Niger and their strong association with improved human welfare demonstrate that even poor countries could achieve sustainable development enshrined in the United Nations Green Economy initiative (UNEP 2011). Enhancing government effectiveness by giving communities a mandate to manage natural resources, and by giving incentives to land users to benefit from their investment, played a key role in realizing simultaneous improvement in land management and human welfare in Niger. The country also learned hard lessons from its past mistakes that involved policies which provided disincentive to land investment and the consequent land degradation that was amplified by prolonged drought. The results further suggest that severe land degradation and the consequent negative impacts on human welfare is low-hanging fruit that needs to be utilized by countries as they address land degradation. This suggests instead of abandoning severely degraded lands, strategies should be used to rehabilitate such lands using low-cost organic soil fertility management practices and progressively followed by using high cost inputs as soil fertility improve. Improvement of access to rural services and facilitation of non-farm activities will also lead to faster and greater impacts on adoption of SLM practices and increasing resilience to production in Niger.

As Niger continues to improve sustainable land management, it faces daunting challenges to alleviate the high cost of land degradation. Niger serves as a success story to the world in addressing land degradation. Both the national and international community need to learn from the achievement of Niger and help land users to sustainably management their natural resources. 
Open Access This chapter is distributed under the terms of the Creative Commons Attribution Noncommercial License, which permits any noncommercial use, distribution, and reproduction in any medium, provided the original author(s) and source are credited.

\section{References}

Adam, T., Reij, C., Abdoulaye, T., Larwanou, M., \& Tappan, G. (2006). Impacts des Investissements dans la Gestion des Resources Naturalles (GRN) au Niger: Rapport de Synthese. Niamey, Niger: Centre Régional d'Enseignement Specialise en Agriculture.

AGRA (Alliance for a Green Revolution in Africa). (2014). Africa Agriculture Report 2014. Climate change and smallholder agriculture in Sub-Saharan Africa. AGRA, Nairobi. Online at www.agra.org.

AMCOW (African Ministers Council on Water). (2011). Water Supply and Sanitation in Niger. AMCOW Country Status Overview.

Anyamba, A., Small, J. L., Tucker, C. J., \& Pak, E. W. (2014). Thirty-two years of Sahelian Zone growing season non-stationary NDVI3g patterns and trends. Remote Sensing, 6, 3101-3122.

Bationo, A., \& Ntare, B. R. (2000). Rotation and nitrogen fertilizer effects on pearl millet, cowpea and groundnut yield and soil chemical properties in a sandy soil in the semi-arid tropics, Africa. Journal of Agricultural Sciences, 134(3), 277-284.

Bayala J. J. B., Teklehaimanot, Z., Kalinganire, A., \& Ouèdraogo, S. J. (2014). Parklands for buffering climate risk and sustaining agricultural production in the Sahel of West Africa. Current Opinion in Environmental Sustainability, 6, 28-34.

Behnke, R. H., \& Scoones, I. (1993). Rethinking range ecology: Implications for rangeland management in Africa. In R. H. Behnke, I. Scoones, \& C. Kerven (Eds.), Range ecology at disequilibrium (pp. 1-30). London: Overseas Development Institute.

Blench, R. (1999). Traditional livestock breeds: Geographical distribution and dynamics in relation to the Ecology of West Africa. Working Paper 122, Overseas Development Institute, Portland House, Stag Place, London. (http://www.odi.org.uk/resources/download/2041.pdf). Accessed on June 1, 2014.

Blum, R. W. (2007). Youth in Sub-Saharan Africa. Journal of Adolescent Health, 41(3), 230-238.

Boffa, J. M. (1999). Agroforestry parklands in Sub-Saharan Africa. FAO Conservation Guide 34. Rome: Food and Agriculture Organization of the United Nations (FAO). http://www.fao.org/ docrep/005/X3940e/X3940e07.htm.

Boudet, G. (1975). Manuel sur les pâturages tropicaux et les cultures fourragères. Coll Manuels et Précis D’élevages (IEMVT ed.). Paris: du Ministère de la Coopération.

Brough, W. \& Kimeny, M. (2002). "Desertification" of the Sahel-exploring the role of property rights. Bozeman, Mt: Property and environment resource Center. Retrieved from http://www. perc.org/perc.php?id=142.

CBA (Community-Based Adaptation Programme) (2010). Niger-Fast facts. CBA: New York.

CNEDD. (2005). Programme d'Action National pour l'Adaptation. Communautés et Zones Vulnérables: Identification et Hiérarchisation des Secteurs.

Cooke, P., Köhlin, G., \& Hyde, W. F. (2008). Fuelwood, forests and community managementevidence from household studies. Environment and Development Economics, 13(1), 103-135.

Cooper, P. J. M., Rao, K. P. C., Singh, P., Dimes, J., Traore, P. S., Rao, K., et al. (2009). Farming with current and future climate risk: Advancing a 'Hypothesis of Hope' for rainfed agriculture in the semi-arid tropics. Journal of SAT Agricultural Research, 7, 1-19.

Cooper, P. J. M., \& Coe, R. (2011). Assessing and addressing climate-induced risk in Sub-Saharan Rainfed agriculture foreword to a special issue of experimental agriculture. Experimental Agriculture, 47(2), 179-184.

CRED (Center for Research on the Epidemiology of Disasters). (2014). International Disaster Database. http://www.emdat.be/result-country-profile. Accessed September 30, 2014. 
de Leeuw, P. N., \& Tothill, J. C. (1993). The concept of rangeland carrying capacity in Sub-Saharan Africa - myth or reality. In R. H. Behnke Jr, I. Scoones, \& C. Kerven (Eds.), Range ecology at disequilibrium. New models of natural variability and pastoral adaptation in African Savannas (pp. 77-88). London: IIED, Overseas Development Institute.

Desta K. B (2002). Analyses of Dairy Cattle Breeding Practices in Selected Areas of Ethiopia. PhD Dissertation submitted to zur Erlangung des akademischen Grades doctor rerum agriculturarum, Berlin. Humboldt University.

FAO. (2014). State of the World's Forests. Enhancing the socioeconomic benefits from forests.

FAO (Food and Agriculture organization). (2012). State of the World's Forests. Rome: FAO.

FAOSTAT. (2014). Food and agriculture Organization corporate database. Available at http:// faostat3.fao.org/faostat-gateway/go/to/home/E. Accessed August 12, 2014.

Garrity, D. P., Akinnifesi, F.K., Ajayi, O. C., Weldesemayat, S.G., Mowo, J.G., Kalinganire, A., Larwanou, M., \& Bayala, J. (2010). Evergreen agriculture: A robust approach to sustainable food security in Africa. Food Security, 2, 197-214.

Gibbs, H. K., Ruesch, A. S., Achard, F., Clayton, M. K., Holmgren, P., Ramankutty, N., \& Foley, J. A. (2010). Tropical forests were the primary sources of new agricultural land in the 1980s and 1990s. Proceedings of the National Academy of Sciences of the United States, 107(38), $16732-16737$.

Gnoumou Y., \& Bloch, P. (2003). Niger country brief: Property rights and land markets.

Havlík, P., Valin, H., Herrero, M., Obersteiner, M., Schmid, E., Rufino, M. C., et al. (2014). Climate change mitigation through livestock system transitions. Proceedings of the National Academy of Science, 111(10), 3709-3714.

Hayashi, K., Matsumoto, N., Tobita, S., Shinjo, H., Tanaka, U., Boubachar, I., \& Tabo, R. (2010). Technology development of soil fertility management based on understanding local agricultural systems of the Sahel in Niger, West Africa. Presented at the 19th World Congress of Soil Sciences, Soil Solutions for a Changing World.

Herrmann, S. M., Anyamba, A., \& Tucker, C. J. (2005). Recent trends in vegetation dynamics in the African Sahel and their relationship to climate. Global Environmental Change, 15, 394-404.

Hiernaux, P., Ayantunde, A., Kalilou, A., Mougin, E., Gérard, B., Baup, F., et al. (2014). Trends in productivity of crops, fallow and rangelands in Southwest Niger: Impact of land use, management and variable rainfall. Journal of Hydrology, 375(1-2), 65-77.

Horace, W., \& Oaxaca, (2006). Results on the bias and inconsistency of ordinary least squares for the linear probability model. Economics Letters, 90(3), 321-327.

Houérou, H. N. Le, \& Hoste, H. (1977). Rangeland production and Annual rainfall relations in the mediterranean basin and in the African Sahelo-Sudanian zone. Journal of Range Management, 30(3), 181-189.

Hüttner, K., Leidl, K., Pfeiffer, D. U., Kasambara, D., \& Jere, F. B. D. (2001). The effect of a community-based animal health service programme on livestock mortality, off-take and selected husbandry applications: A field study in Northern Malawi. Livestock Production Science, 72(3), 263-278.

INS (Institut National de la Statistique). (2012). Living standards measurement survey (LSMS) Agriculture household survey, 2012.

Izzaurralde, R. C. (2010). Nigeria. Simulation of sustainable land management practices. Mimeo: IFPRI.

Jaspa, I. L. O. (1981). First things first: Meeting the basic needs people of Nigeria. Geneva: ILO.

Just, R., \& Pope, R. D. (1979). Production function estimation and related risk considerations. American Journal of Agricultural Economics, 61(2), 276-284.

Just, R., \& Pope, R. D. (2003). Agricultural risk analysis: Adequacy of models, data, and issues. American Journal of Agricultural Economics, 85(5), 1249-1256.

Kaizzi, C. K. (2002). The potential benefit of green manures and inorganic fertilizers in cereal production on contrasting soils in eastern Uganda. Ph.D. Dissertation., University of Bonn and German Center for Development Research (ZEF), Germany, pp. 64-69. 
Kamuanga, M., Somda, J., Sanon, Y., \& Kagoné, H. (2008). The future of livestock in the Sahel and West Africa: Potentials and challenges for strengthening the regional market. OECD. http://www.oecd.org/swac/publications/38402714.pdf. Accessed October 8, 2014.

Kaphengst, T. (2014). Towards a definition of global sustainable land use? A discussion on theory, concepts and implications for governance. Discussion paper produced within the research project "GLOBALANDS - Global Land Use and Sustainability". http://www.ecologic.eu/ globalands/about.

Kaufmann, D., Kraay, A., \& Mastruzzi, M. (2010). The Worldwide Governance indicators: Methodology and analytical issues. World Bank Policy Research Working Paper No. 5430.

Lavigne-Delville, P., Ouedraogo, H., \& Toulmin, C. (2002). Land tenure dynamics and state intervention: Challenges, ongoing experience and current debates on land tenure in West Africa. In Making land rights more secure', conclusions of a seminar held in Ouagadougou, Burkina Faso, 19-21 March, 2002.

Lavigne-Delville, P., Toulmin, C., Colin, J. P., \& Chauveau, J. P. (2002). Negotiating access to land in West Africa: A synthesis of findings from research on derived rights to land. Land Tenure and Resource Access in West Africa series, IIED, London.

Le Bao, Q. B., Nkonya, E., \& Mirzabaev, A. (2014). Biomass productivity-based mapping of global land degradation hotspots. ZEF-Discussion Papers on Development Policy, (193). University of Bonn.

Mohamadou, A. (2009). Decentralisation and local power in Niger. IIED Issue paper no. 150. Online at http://pubs.iied.org/pdfs/12557IIED.pdf. Accessed October 3, 2014.

Montagne, P., \& Amadou, O. (2012). Rural districts and community forest management and the fight against poverty in Niger. Field actions Sciences reports. Special issue 6. Online at http:// factsreports.revues.org/1473. Accessed January 12, 2015.

Muia J. M. (2000). Use of Napier grass to improve smallholder milk production in Kenya. PhD Thesis Wageningen University, Wageningen, The Netherlands.

Muia, J. M., Tamminga, S., \& Mbugua, P. N. (2000). Effect of supplementing napier grass (Pennisetum purpureum) with sunflower meal or poultry litter-based concentrates on feed intake, live-weight changes and economics of milk production in Friesian cows. Livestock Production Science, 67, 89-99.

Nkonya, E., Pender, J., Kaizzi, K., Kato, E., Mugarura, S., Ssali, H., \& Muwonge. J. (2008). Linkages between land management, land degradation, and poverty in Sub-Saharan Africa: The case of Uganda. IFPRI Research Report \#159, Washington, D.C.

Nkonya, E., Place, F., Kato, E., \& Mwanjololo, M. (2015). Climate risk management through sustainable land management in Sub-Saharan Africa. In R. Lal B. Singh, D. Mwaseba, D. Kraybill, D. Hansen, \& L. Eik, (eds.), Sustainable intensification to advance food security and enhance climate resilience in Africa, Springer International Publishing, Switzerland, pp. 75112. doi:10.1007/978-3-319-09360-4_5.

North, D. (1991). Institutions. Journal of Economic Perspectives, 5(1), 97-112.

NRC (National Research Council). (2001). Nutrient Requirements of Dairy Cattle (7th ed.). Washington, D.C.: National Academy Press.

Otte, M. J., \& Chilonda, P. (2002). Cattle and small ruminant production systems in sub-Saharan Africa. Food and Agriculture Organization (FAO), Rome: A Systematic Review.

Otte, J., \& Chilonda, P. (2011). Spatial livestock production modelling. In Robinson, T., \& P. Thornton, (Eds.), Global mapping of agricultural production systems. Pro-poor Livestock Policy Initiative Meeting Report, Bangkok, Thailand, 4-6 April 2006.

Ouedraogo, I., Runge, J., Eisenberg, J., Barron, J., \& Sawadogo-Kaboré, S. (2013). The re-greening of the Sahel: Natural cyclicity or human-induced change? Land, 3, 1075-1090.

Pender, J. (2009). Impacts of sustainable land management programs on land management and poverty in Niger. World Bank Report No.: 48230-NE.

Pender, J., Abdoulaye, T., Ndjeunga, J., Gerard, B. \& Kato, E. (2008). Impacts of inventory credit, input supply shops, and fertilizer micro-dosing in the Drylands of Niger. IFPRI Discussion Paper No. 763. Washington, D.C.: International Food Policy Research Institute. 
Penning de Vries, F. W. T., \& Djitèye, M. A. (1982). La Productivité des Pâturages Sahéliens, une Étude des Sols, des Végétations et de L'exploitation de Cette Ressources Naturelle. Wageningen: Centre for Agricultural Publishing and Documentation.

Peterman, A., Behrman, J.A. \& Quisumbing, A.R. (2014). A review of empirical evidence on gender differences in nonland agricultural inputs, technology, and services in developing countries. In A.R. Quisumbing, R. Meinzen-Dick, T. L. Raney, A. Croppenstedt, J.A. Behrman, \& A. Peterman (Eds.), Gender in agriculture Springer Netherlands, pp. 145-186.

Pieri, C. (1989). Fertilité des terres de savanes. Bilan de trente ans de recherche et de développement agricole au sud du Sahara. Ministère de la Coopération/CIRAD/IRAT, Paris.

Place, F. \& Binam, J.N. (2013). Economic impacts of farmer managed natural regeneration in the Sahel. End of project technical report for the Free University Amsterdam and IFAD. Nairobi, World Agroforestry Centre.

Reij, C., Tappan, G., \& Smale, M. (2009). Re-Greening the Sahel: Farmer-led innovation in Burkina Faso and Niger. In D. Spielman \& R. Pandya-Lorch (Eds.), Millions Fed. Proven Successes in Agricultural Development (pp. 53-58). Washington, DC: IFPRI.

République du Niger. (2003). Strategie de Developpement Rural. Niamey, Niger: Cabinet du Premier Ministre, Secretariat Permanent de la SRP.

Reynolds, J. F., Grainger, A., Stafford Smith, D. M., Bastin, G., Garcia-Barrios, L., Fernández, R. J., et al. (2011). Scientific concepts for an integrated analysis of desertification. Land Degradation and Development, 22, 166-183.

Rinaudo, T. (2005). Uncovering the underground Forest: A short History and description of Farmer managed natural regeneration. Melbourne: World Vision.

RoN (Republic of Niger). (2006). National adaptation programme of action.

Rufino, M. C., Herrero, M., Van Wijk, M. T., Hemerik, L., De Ridder, N., \& Giller, K. E. (2009). Lifetime productivity of dairy cows in smallholder farming systems of the central highlands of Kenya. Animal, 3(07), 1044-1056.

Sahara Conservation Fund. (2007). Niger creates the largest protected area in Africa. http://www. saharaconservation.org/?Niger-creates-the-largest.

Steeg, J. van de, M. Herrero, \& Notenbaert, A. (2013). Supporting the vulnerable: Increasing adaptive capacities of agropastoralists to climate change in West and southern Africa using a transdisciplinary research approach. Nairobi, Kenya: International Livestock Research Institute (ILRI).

Sendzimir, J., Reij, C. P., \& Magnuszewski, P. (2011). Rebuilding resilience in the Sahel: Regreening in the Maradi and Zinder regions of Niger. Ecology and Society, 16(3), 1.

Stéphenne, N., \& Lambin, E. F. (2001). A dynamic simulation model of land-use changes in Sudano-sahelian countries of Africa (SALU). Agriculture, Ecosystems and Environment, 85, $145-161$.

Stickler, M. (2012). Rights to trees and livelihoods in Niger. Focus on land in Africa. Placing land rights at the heart of development. Brief. www.focusonland.com/download/51c49667b7626/.

Tabo, R., Bationo, A., Hassane, O., Amadou, B., Fosu, M., Sawadogo-Kabore, S., Fatondji, D., Korodjouma, O., Abdou, A., \& Koala, S. (2009). Fertilizer microdosing for the prosperity of resource poor farmers: A success story. In: Humphreys, E. \& R.S. Bayot (Eds.), (2009). Increasing the productivity and sustainability of rainfed cropping systems of poor smallholder farmers. In Proceedings of the CGIAR Challenge Program on Water and Food International Workshop on Rainfed Cropping Systems, Tamale, Ghana, 22-25 September 2008. The CGIAR Challenge Program on Water and Food, Colombo, Sri Lanka.

Tittonell, P., \& Giller, K. E. (2013). When yield gaps are poverty traps: The paradigm of ecological intensification in African smallholder agriculture. Field Crops Research, 143, 76-90.

Toulmin, C., \& Quan, J. (2000). Evolving land rights, policy and tenure in Africa. International Inst. for Environment and Development, London. $336 \mathrm{pp}$.

Twomlow, S., Hove, L., Mupangwa, W., Masikati, P., \& Mashingaidze, N. (2009). Precision conservation agriculture for vulnerable farmers in low potential zones. In: Humphreys, E. \& R. S. Bayot, (Eds.), Increasing the productivity and sustainability of rainfed cropping systems of poor smallholder farmers. Proceedings of the CGIAR Challenge Program on Water and Food 
International Workshop on Rainfed Cropping Systems, Tamale, Ghana, 22-25 September 2008. The CGIAR Challenge Program on Water and Food, Colombo, Sri Lanka.

UNDP. (2014). Human Development Report 2014. Sustaining Human Progress: Reducing Vulnerabilities and Building Resilience. http://hdr.undp.org/sites/default/files/hdr14-report-en1.pdf. Accessed September 30, 2014.

UNDP (United Nations Development Program). (2013). Human Development Report. The Rise of the South: Human Progress in a Diverse World. New York, pp 203.

Upton, M. (1989). Livestock productivity assessment and herd growth models. Agricultural Systems, 29(2), 149-164.

WHO (World Health Organization) (2014). World Health Statistics. http://apps.who.int/iris/ bitstream/10665/112738/1/9789240692671_eng.pdf?ua=1. Accessed October 6, 2014.

World Bank. (2011). Africa emergency locust project. Online at http://www-wds.worldbank.org/ external/default/WDSContentServer/WDSP/IB/2012/01/11/000333037_20120111005226/

Rendered/PDF/ICR15530P092570IC0disclosed01090120.pdf. Accessed June 12, 2014.

Vanlauwe, B., \& Giller, K. E. (2006). Popular myths around soil fertility management in sub-Saharan Africa. Agriculture, Ecosystems and Environment, 116(1), 34-46.

Von Grebmer, K., Headey, D., Olofinbiyi, T., Wiesmann, D., Fritschel, H., Yin, S., \& Yohannes, Y. (2013). Global hunger index the challenge of hunger: Building resilience to achieve food and nutrition security. IFPRI. http://www.ifpri.org/publication/2013-global-hunger-index.

Winslow, M. D., Vogt, J. V., Thomas, R. J., Sommer, S., Martius, C., \& Akhtar-Schuster, M. (2011). Science for improving the monitoring and assessment of dryland degradation. Land Degradation \& Development, 22(2), 145-149.

Zingore, S., Murwira, H. K., Delve, R. J., \& Giller, K. E. (2007). Influence of nutrient management strategies on variability of soil fertility, crop yields and nutrient balances on smallholder farms in Zimbabwe. Agriculture, Ecosystems and Environment, 119, 112-126. 